\title{
Laboratory Scale Vitrification of Low-Level Radioactive Nitrate Salts and Soils from the Idaho National Engineering Laboratory
}

\author{
Peter Shaw \\ Brenda Anderson ${ }^{a}$ \\ Douglas Davis ${ }^{b}$
}

Published July 1993
Idaho National Engineering Laboratory
EG\&G Idaho, Inc.
Idaho Falls, Idaho 83415

Prepared for the

U.S. Department of Energy

Office of Environmental Restoration and Waste Management

Under DOE Idaho Operations Office

Contract DE-AC07-76ID01570 


\section{DISCLAIMER}

This report was prepared as an account of work sponsored by an agency of the United States Government. Neither the United States Government nor any agency thereof, nor any of their employees, make any warranty, express or implied, or assumes any legal liability or responsibility for the accuracy, completeness, or usefulness of any information, apparatus, product, or process disclosed, or represents that its use would not infringe privately owned rights. Reference herein to any specific commercial product, process, or service by trade name, trademark, manufacturer, or otherwise does not necessarily constitute or imply its endorsement, recommendation, or favoring by the United States Government or any agency thereof. The views and opinions of authors expressed herein do not necessarily state or reflect those of the United States Government or any agency thereof. 


\section{DISCLAIMER}

Portions of this document may be illegible in electronic image products. Images are produced from the best available original document. 
Laboratory Scale Vitrification of Low-Level Radioactive Nitrate Salts and Soils from the Idaho National Engineering Laboratory

EGG-WTD-10640

Prepared by

Peter \& flow

P. G. Shaw

Environmental Restoration Technology Development

Reviewed by

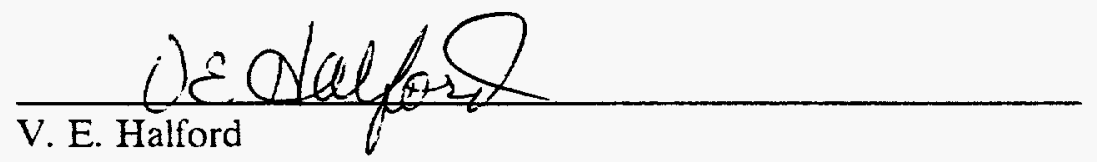

Environmental Restoration Department

Approved by

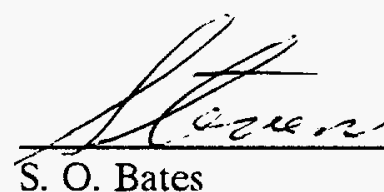

Environmental Restoration Technology Development

$$
\frac{7 / 14 / 93}{\text { Date }}
$$
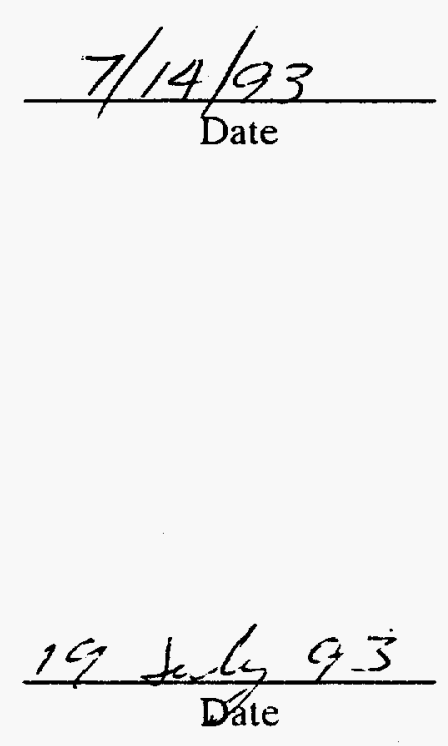


\section{ABSTRACT}

The Idaho National Engineering Laboratory (INEL) has radiologically contaminated nitrate salt and soil waste stored above and belowground in Pad A and the Acid Pit at the Radioactive Waste Management Complex. Pad A contains uranium and transuranic contaminated potassium and sodium nitrate salts generated from dewatered waste solutions at the Rocky Flats Plant. The Acid Pit was used to dispose of liquids containing waste mineral acids, uranium, nitrate, chlorinated solvents, and some mercury. Some of these wastes may be mixed hazardous low-level radioactive wastes and may require treatment. Ex situ vitrification is a high temperature destruction of nitrates and organics and immobilizes hazardous and radioactive metals (known as wasteforms). Laboratory scale melting of actual radionuclides containing INEL Pad A nitrate salts and Acid Pit soils was performed. The salt/soil/additive ratios were varied to determine the range of glass compositions (resulted from melting different wastes); maximize mass and volume reduction, durability, and immobilization of hazardous and radioactive metals; and minimize viscosity and offgas generation for wastes prevalent at INEL and other U.S. Department of Energy sites. The resulting wasteforms after thermal processing occupied less volume ( 28 to $76 \%$ less) and mass (up to $42 \%$ less) than the wastes. Some mixtures were spiked with additional hazardous and radioactive metals. Representative glasses were leach tested and showed none. Samples spiked with transuranic showed low nuclide leaching. Wasteforms were two to three times bulk densities of the salt and soil. Thermally co-processing soils and salts is an effective remediation method for destroying nitrate salts while stabilizing the radiological and hazardous metals they contain. The measured durability of these low-level waste glasses approached those of high-level waste glasses. Lab scale vitrification of actual INEL contaminated salts and soils was performed at General Atomics Laboratory as part of the INEL Waste Technology Development and Environmental Restoration within the Buried Waste Integrated Demonstration Program. 


\section{SUMMARY}

The Idaho National Engineering Laboratory (INEL) has radiologically contaminated nitrate salts, sludges, and soils stored above and belowground in places such as Pad A and the Acid Pit at the Radioactive Waste Management Complex (RWMC). The Pad A site contains an estimated $8,100 \mathrm{~m}^{3}$ of plutonium-contaminated nitrate salt waste generated by the Rocky Flats Plant. The Acid Pit was used to dispose of acidic, liquid, low-level wastes containing uranium, nitrate salts, chlorinated solvents, low levels of mercury, and Cs-137. These two sites provide examples of wastes found throughout the U.S. Department of Energy's (DOE's) weapons complex.

In order to establish an acceptable treatment method for Pad A waste, EG\&G Idaho, Inc. (EG\&G Idaho), solicited proposals to treat the waste with the objective of destroying the hazardous nitrates, and producing a low-level wasteform suitable for long-term storage. The ex situ vitrification process proposed by General Atomics' (GA) Nuclear Remediation Technologies (NRT) Division was selected. This technology utilized an ex situ joule heated vitrification melter with cold-cap for these mixed hazardous, low-level radioactive wastes because of the capability to destroy the nitrates, fixate metals and radionuclides, achieve significant volume reduction and limit hazardous offgas releases.

Originally proposed as a two-phased project (laboratory-scale and pilot-scale), only the first phase laboratory-scale work was funded. Also the scope was expanded to cover processing of soil (i.e., that from the INEL Acid Pit); in lieu of additive sand, resulting in the demonstration of a co-vitrification process that would treat both the contaminated nitrate salts as well as contaminated soil, further enhancing the value added by the process.

This report discusses the results of the Phase I laboratory-scale vitrification testing program where a variety of glasses was produced from samples of Pad A nitrate salts and Acid Pit soil in GA's Radiochemistry Laboratory. These glasses were then characterized and tested at GA, Pacific Northwest Laboratory and INEL. The primary purpose of the Phase I testing was to identify acceptable salt/soil/additive formulations for implementation in the Phase II pilot-scale testing. The laboratory-scale demonstration consisted of sample characterization, the melting of actual salt/soil wastes, and final wasteform characterization activities.

A series of tests was conducted in crucibles in a $1550^{\circ} \mathrm{C}$ bench-top furnace contained in a ventilation hood. Over thirty $100-\mathrm{g}$ glass wasteforms were produced. The total activity of the processed salts and soils was $<200 \mathrm{pCi} / \mathrm{g}$, with most of the activity from depleted uranium. The salt/soil/additive ratios were varied to determine the range of useful glass compositions for immobilization of low-level radioactive wastes from INEL and other DOE sites. Mixtures of Pad A salt and Acid Pit soils ranged from 20 to $60 \%$ salt and 40 to $80 \%$ soil. Glass redox was controlled using additives such as boric acid and activated carbon.

Two glass wasteforms, a low (16\%) and high (22\%) alkali formulation, were submitted to the Environmental Protection Agency toxic characteristic leach procedure and found to be leach-resistant for both hazardous and radioactive components. Six glass wasteforms from low (18\%) to very high (39\%) alkali were tested by the Nuclear Regulatory Commission Product Characterization Test. Waste volume was reduced typically over $60 \%$ and mass reduced over $10 \%$. The laboratory-scale tests have shown the feasibility of the co-vitrification process to successfully destroy nitrates, fixate the metal and radionuclide constituents, and very significantly reduce stored low-level waste volume. 
Appropriate glass formulations, suitable for progressing to the Phase II pilot-scale demonstration, have been identified. Technical issues relating to the capture and reflux of volatile species into the melt and the measurement and control of oxides of nitrogen emissions will be resolved during the Phase II testing under actual cold-cap operating conditions. NRT proposed to perform the Phase II testing at the RWMC at INEL, but could optionally perform the testing at NRT's San Diego facility.

This testing was performed as part of the INEL Technology Development/Environmental Restoration Demonstration Projects within the Buried Waste Integrated Demonstration Program. 


\section{CONTENTS}

ABSTRACT $\ldots \ldots \ldots \ldots \ldots \ldots \ldots \ldots \ldots \ldots \ldots \ldots \ldots \ldots \ldots \ldots \ldots \ldots \ldots \ldots \ldots$

SUMMARY $\ldots \ldots \ldots \ldots \ldots \ldots \ldots \ldots \ldots \ldots \ldots \ldots \ldots \ldots \ldots \ldots \ldots \ldots \ldots \ldots$

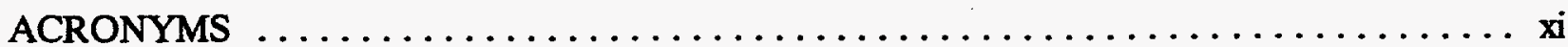

1. INTRODUCTION $\ldots \ldots \ldots \ldots \ldots \ldots \ldots \ldots \ldots \ldots \ldots \ldots \ldots \ldots \ldots \ldots$

1.1 Report Objective $\ldots \ldots \ldots \ldots \ldots \ldots \ldots \ldots \ldots \ldots \ldots \ldots \ldots \ldots \ldots \ldots \ldots$

1.2 Joule-Heated Vitrification Technology $\ldots \ldots \ldots \ldots \ldots \ldots \ldots \ldots \ldots \ldots$

1.2.1 Joule-Heated Vitrification Process Description . . . . . . . . . . . 1

1.2.2 Technology and Vendor Selection $\ldots \ldots \ldots \ldots \ldots \ldots \ldots \ldots \ldots$

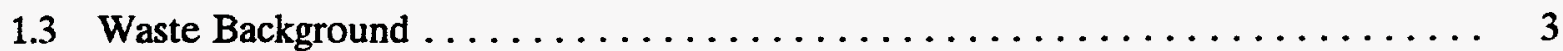

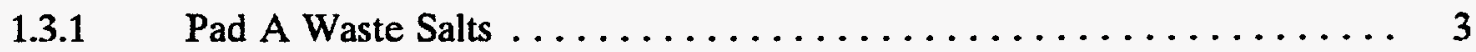

1.3.2 Acid Pit Contaminated Soil $\ldots \ldots \ldots \ldots \ldots \ldots \ldots \ldots \ldots \ldots \ldots$

2. LABORATORY SCALE EX SITU VITRIFICATION OF NITRATE SALTS AND

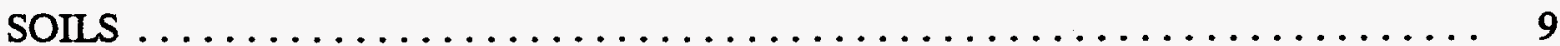

2.1 Experimental Description $\ldots \ldots \ldots \ldots \ldots \ldots \ldots \ldots \ldots \ldots \ldots \ldots \ldots \ldots \ldots \ldots$

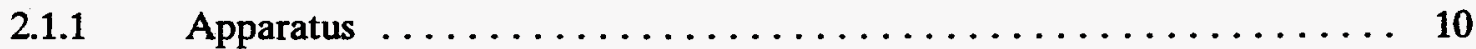

2.1.2 Waste Materials Pad A Salt and Acid Pit Soil

Preparation. ...................... 10

2.2 Experimental Procedure-High Temperature Furnace Melting of

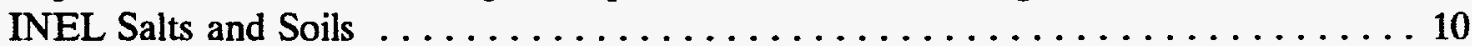

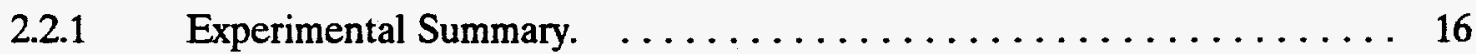

2.2.2 Characterization and Wasteform Leach Testing $\ldots \ldots \ldots \ldots \ldots \ldots$

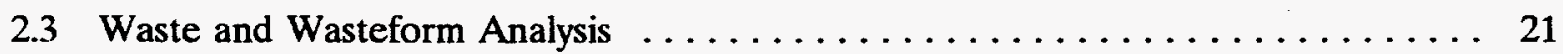

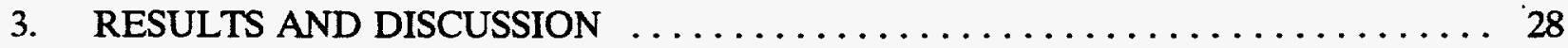

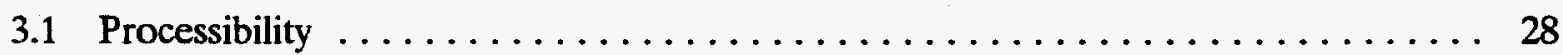

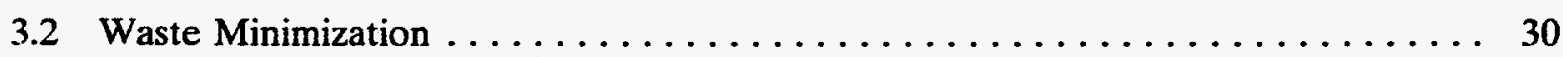

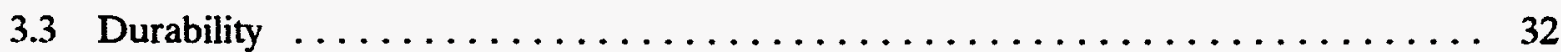


4. QUALITY ASSURANCE/CONTROL $\ldots \ldots \ldots \ldots \ldots \ldots \ldots \ldots \ldots \ldots \ldots \ldots$

4.1 QA Laboratory Audits and Surveillance $\ldots \ldots \ldots \ldots \ldots \ldots \ldots \ldots \ldots \ldots \ldots \ldots \ldots$

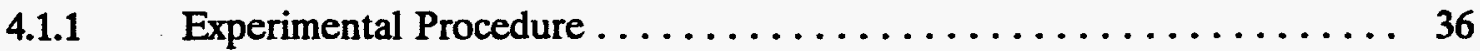

4.1.2 Laboratory Data $\ldots \ldots \ldots \ldots \ldots \ldots \ldots \ldots \ldots \ldots \ldots \ldots \ldots \ldots \ldots$

5. CONCLUSIONS AND RECOMMENDATIONS $\ldots \ldots \ldots \ldots \ldots \ldots \ldots \ldots \ldots$

5.1 Conclusions $\ldots \ldots \ldots \ldots \ldots \ldots \ldots \ldots \ldots \ldots \ldots \ldots \ldots \ldots \ldots \ldots \ldots \ldots$

5.2 Recommendations $\ldots \ldots \ldots \ldots \ldots \ldots \ldots \ldots \ldots \ldots \ldots \ldots \ldots \ldots$

REFERENCES $\ldots \ldots \ldots \ldots \ldots \ldots \ldots \ldots \ldots \ldots \ldots \ldots \ldots \ldots \ldots \ldots \ldots \ldots$

\section{FIGURES}

1. Pad A and Acid Pit sites at Radioactive Waste Management Complex at the INEL ... 4

2. Pad A waste prior to closure (1977) $\ldots \ldots \ldots \ldots \ldots \ldots \ldots \ldots \ldots \ldots \ldots \ldots \ldots$

3. Pad A after closure with soil overburden (white structure shows locations of 1989 Initial Penetration Project) $\ldots \ldots \ldots \ldots \ldots \ldots \ldots \ldots \ldots \ldots \ldots \ldots \ldots \ldots \ldots \ldots$

4. Arrangements of melt furnace and annealing oven $\ldots \ldots \ldots \ldots \ldots \ldots \ldots \ldots$

5. Soil and salt samples $\ldots \ldots \ldots \ldots \ldots \ldots \ldots \ldots \ldots \ldots \ldots \ldots \ldots \ldots \ldots \ldots \ldots$

6. Electrode materials to be used in corrosion tests $\ldots \ldots \ldots \ldots \ldots \ldots \ldots \ldots \ldots$

7. Glass cast from Melt $\# 58 \ldots \ldots \ldots \ldots \ldots \ldots \ldots \ldots \ldots \ldots \ldots \ldots \ldots \ldots$

8. Glass cast from Melt $\# 68$, top of glass is glossy $\ldots \ldots \ldots \ldots \ldots \ldots \ldots \ldots \ldots \ldots$

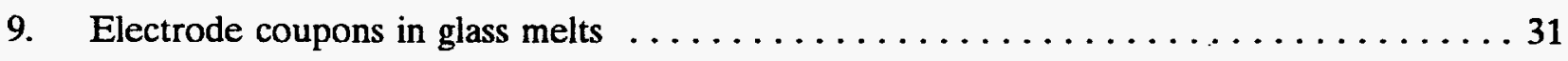

\section{TABLES}

1. Summary of nitrate salt waste storage and generation in defense facilities $\ldots \ldots \ldots 7$

2. Laboratories characterizing Pad A salt, acid pit soil and glass wasteform ........ 13

3. Oxide composition of Pad A salt, Acid Pit soil, and a final glass wasteform . . . . . 15 
4. Laboratory testing summary $\ldots \ldots \ldots \ldots \ldots \ldots \ldots \ldots \ldots \ldots \ldots \ldots \ldots \ldots$

5. Elemental composition of Pad A salt, acid pit soil, and a final glass wasteform . . . . . 23

6. Nonmetal composition of Pad A salt, Acid Pit soil, and a final glass wasteform . . . . . . 24

7. Radionuclide content of Pad A salt, Acid Pit soil, and glass wasteforms $\ldots \ldots \ldots 25$

8. Metals and radionuclides leached from a 35\% Pad A salt glass wasteform during TCLP

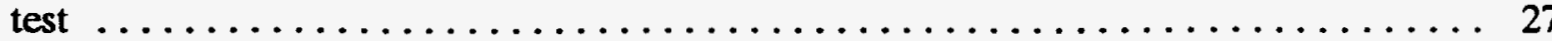

9. Waste minimization and processability of INEL Pad A nitrate salt and Acid Pit soil at $1500^{\circ} \mathrm{C}-1575^{\circ} \mathrm{C}$

10. Metal leaching from glass wasteforms during $\mathrm{PCT}$ test $\ldots \ldots \ldots \ldots \ldots \ldots \ldots$

11. Laboratory reproducibility and similarity of hot and simulate duplicate melts $\ldots \ldots \ldots 37$

12. Comparison of Pad A salt and acid pit soil results by destructive and nondestructive

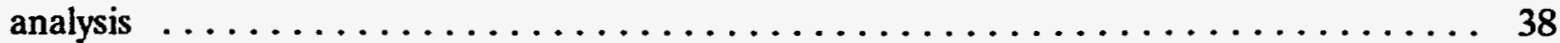

13. Comparison of Pad A salt TCLP metals results by destructive and nondestructive analysis 39

14. Comparion of NIST standard glass values with measured results by destructive ICP analysis

15. Expected vs. measured metals content of glass by destructive ICP analysis $\ldots \ldots \ldots 41$

16. Expected vs. measured $\mathrm{Na}, \mathrm{K}$, and $\mathrm{Cr}$ content of glass by nondestructive INAA analysis . 42

17. Laboratory reproducibility of duplicate melts with Pad A salt and Acid Pit soil ........

18. Comparison of Pad A salt radionuclide results by destructive alpha spectrometry nondestructive gamma spectrometry 


\section{ACRONYMS}

AA

AAS

AES

CERCLA

DOE

EC

ECL

EG\&G Idaho

EPA

ERD

ICP

IEB

INAA

INEL

LLW

NAA

NIST

NRC

NRT

NTS

PCT

PNL

QAPD atomic absorption

atomic absorption spectrophotometry

atomic emission spectrometry

Comprehensive Environmental Response, Compensation and Liability Act

U. S. Department of Energy

Environmental Chemistry

Environmental Chemistry Lab, INEL

EG\&G Idaho, Inc.

Environmental Protection Agency

Environmental Restpration Department

inductively coupled plasma

iron enriched basalt

Instrumental Neutron Activation Analysis

Idaho National Engineering Laboratory

low-level waste

Neuron Activation Analysis

National Institute of Standards and Technology

Nuclear Regulatory Commission

Nuclear Remediation Technologies, a division of General Atomics

Nevada Test Site

Product Characterization Test

Pacific Northwest Laboratory

quality assurance program document 
QC

RFP

RML

RPD

RWMC

TCT

TCLP

TRU quality control

Rocky Flats Plant

Radiations Measurement Laboratory

relative percent difference

Radioactive Waste Management Complex

Tri Cities Testing, St. Louis-Chemical Laboratory

toxicity characteristics leaching procedure

transuranic 


\section{Laboratory Scale Vitrification of Low-Level Radioactive Nitrate Salts and Soils from the Idaho National Engineering Laboratory}

\section{INTRODUCTION}

\subsection{Report Objective}

The primary objective of the laboratory-scale vitrification testing was to demonstrate the effectiveness of the vitrification treatment for radionuclide-contaminated nitrate salts and soils, such as those represented by samples from Pad A and the Acid Pit. This report documents waste and wasteform characterization from laboratory-scale vitrification, of salt samples taken from Pad A and soil samples from the Acid Pit.

The primary objective of the laboratory-scale ex situ vitrification test was to determine if the co-processing of soils and salts is an effective remediation method for destroying nitrate salts while stabilizing the radiologically contaminated soils. The test was to provide the range of salt/soil/additive compositions, in which the primary criteria are (a) fixation of radiological contaminants, (b) destruction of nitrates, and (c) minimization of overall volume and mass. The glass composition data are to be used in the pilot-scale test following this laboratory-scale test. The implementability and specific processing parameters, including the effectiveness of cold-cap vitrification in reducing hazardous offgas, are to be determined in the pilot-scale test.

\subsection{Joule-Heated Vitrification Technology}

Vitrification is a process that produces glassy solids from wastes, and glass forms by melting the materials at high temperatures. Offgas from waste vitrification processes are treated to remove acids, particulates, and other potentially hazardous constituents. Vitrification has been used for a wide range of waste types, from high-level radioactive waste (ex situ) to contaminated soil still in the ground (in situ). ${ }^{1,4}$ Ex situ vitrification, using joule heating was the selected method for the coprocessing of the soil and salt wastes described in this report. ${ }^{4}$

\subsubsection{Joule-Heated Vitrification Process Description}

Ex situ joule-heated vitrification can treat wastes of various forms-from slurries to powder-with a wide range of such characteristics as salinity, $\mathrm{pH}$, and heavy metal and other contaminant concentrations. It can (a) reduce waste volume, (b) minimize residual wastes, (c) immobilize radionuclides and heavy metals, and (d) destroy toxic organics and nitrates; thereby meeting all mixed-waste treatment criteria per the Environmental Protection Agency (EPA). It has been used widely in Germany and Japan for treating incinerator ash, hazardous waste, municipal waste, and sewage sludge. 
This process is (a) reliable, (b) versatile and adaptable, (c) easy to operate, and (d) can be scaled-up readily. Its glassy wasteform is stable, dense, hard, leach-resistant, and can be buried as low-level waste (LLW) for final disposal. It has been identified in the Federal Facilities Agreement/Consent Orders reports as a primary candidate for treating transuranic (TRU)-containing waste and mixed waste and producing an acceptable wasteform that meets toxicity characteristic leaching procedure (TCLP) requirements under Resource Conservation and Recovery Act's Land Disposal Restrictions (LDR)..$^{1-5}$

Implementing the ex situ vitrification method to the co-processing of salt and soil wastes first requires control of exhaust gas composition, flux composition, processing temperature, and durability of final wasteform through laboratory-scale testing. The pilot-scale vitrification test will then define or verify other parameters, such as corrosion resistance of electrode and refractory lining, logistics for large-scale processing, chemistry and rate of fluxing additives to achieve a stable final product, and control of $\mathrm{NO}_{x}$ gases either through exhaust treatment or in-process destruction. Results from the pilot-scale test may then be used to determine the feasibility of co-processing contaminated soil and nitrate salts, and to calculate the thermal efficiency and cost of a full-scale vitrification process.

A binder material is required in vitrification to help dissolve the salts and stabilize the final wasteform. Silica from sand or diatomaceous earth is often added as binder in glass formation. Thus, co-processing of contaminated salts and soil to make glass is an excellent method for achieving substantial waste volume reduction. For highly durable glass, the ideal silica content is between 65 and 70 weight \%; however, silica content as low as $55 \%$ in the presence of other metal oxides can also yield durable glass. The maximum alkali content $\left(\mathrm{Na}_{2} \mathrm{O}\right.$ and $\left.\mathrm{K}_{2} \mathrm{O}\right)$ contributed by the salt should be about $25 \%$, since higher alkali content can reduce glass durability. The melt viscosity increases with decreasing salt content and increasing soil content; therefore, various fluxing agents were added in small quantities to achieve desirable viscosities. Fluxing agents included fluorspar, boric acid, carbonate minerals, and water. Among these additives, boric acid provides an additional benefit: its reaction product, boron oxide, increases the glass durability. ${ }^{4}$

Process temperature is a primary parameter of consideration in vitrification. Process temperature determines the furnace design, heating option and electrode material, flux agents and binder type, waste types, and the final wasteform properties. Processing at temperatures above $1200^{\circ} \mathrm{C}$ requires a refractory brick furnace lining and special electrodes. At higher temperatures, organic destruction is better achieved, and more types of contaminants can be handled. At lower temperatures, $\mathrm{NO}_{\mathrm{x}}$ destruction is better achieved, and design, construction, maintenance, and process control for the melter is simpler and less expensive.

A modification of the ex situ joule-heated vitrification to reduce offgas emission is cold-cap vitrification, the technology proposed by Nuclear Remediation Technologies (NRT). NRT provides waste management and environmental restoration services to the government as well as the commercial sector. ${ }^{5}$ Cold-cap joule-heated vitrification involves feeding wastes and additives to the top of the melter vessel, while electrically heating the melt with joule electrodes inserted through the side of the vessel. Since the waste feed materials remain cold at 50 to $150^{\circ} \mathrm{C}$, as compared to the melt at $1600^{\circ} \mathrm{C}$, volatile materials are condensed in the cold-cap and refluxed into the melt. Oxidation of hazardous organics or reduction of $\mathrm{NO}_{x}$, have time to occur in the cold-cap. The emission of $\mathrm{NO}_{\mathrm{x}}$ gas poses a particular problem when destroying nitrate salts can be reduced in the melter. The 
alternative is to treat the $\mathrm{NO}_{\mathrm{x}}$ gas by scrubbing, which can produce hazardous wastes, or by reduction to form $\mathrm{N}_{2}$ gas using the cold-cap.

Before pilot cold-cap vitrification tests, the following laboratory-scale testing was conducted using a bench-top furnace providing information on the compositions of feed materials, durability of glass product and waste destruction. Results from laboratory-scale testing can be used to plan the compositions used in the pilot-scale testing in a cold-cap melter.

\subsubsection{Technology and. Vendor Selection}

In assessing the potential treatment for salt and soil wastes at the Idaho National Engineering Laboratory (INEL), all potential treatment and separation methods for both radioactive and chemically hazardous components of the waste were first evaluated to identify the most viable methods. A Request for Proposal was then issued to 19 vendors who expressed interests or expertise in the identified technologies. Seven of these vendors responded, and they were screened against four mandatory requirements: (a) prior experience, (b) facilities, (c) established plans, and (d) company commitment. Those who passed these requirements were further down-selected based on the Comprehensive Environmental Response, Compensation, and Liability Act (CERCLA) evaluation criteria: (a) effectiveness of proposed technology, (b) implementability of proposed technology, (c) vendor experience, (d) vendor resources, (e) schedule, and (f) cost. $^{1.4}$

From the evaluation process, ex situ vitrification was determined to be the best treatment technology for testing on radiologically contaminated salt and soil wastes. As the result of the selection phase, the NRT Division of General Atomics was selected as the vendor for the laboratory-scale joule-heated vitrification test.

\subsection{Waste Background}

The INEL Radioactive Waste Management Complex (RWMC) currently contains radiologically contaminated waste including about $4 \%$ of the nitrate salt waste stored at U.S. Department of Energy (DOE) defense facilities. ${ }^{1}$ Some wastes were generated by onsite operations but most are from offsite facilities primarily the Rocky Flats Plant (RFP). The waste sites of particular interests for this project are the salt waste at $\mathrm{Pad} \mathrm{A}^{2}$ which is entirely from RFP. The soil waste at the Acid Pit was generated by on-site operations. The relative locations at the RWMC are shown in Figure 1.

\subsubsection{Pad A Waste Salts}

Pad $\mathrm{A}$ is a ground-level asphalt pad constructed for the aboveground disposal of radioactive contaminated wastes generated by the DOE RFP between 1972 and $1978 .^{2}$ These wastes are composed primarily of nitrate salts, contain less than $10 \mathrm{nCi} / \mathrm{g}$ of TRU radionuclides, and exhibit a dose rate of less than $200 \mathrm{mR} / \mathrm{hr}$ at the surface of each container. ${ }^{2}$ The salt waste is composed of about $90 \%$ sodium and potassium nitrate, with the balance of sodium and potassium sulfates, chlorides, hydroxides, and above background trace concentrations of chromium. 


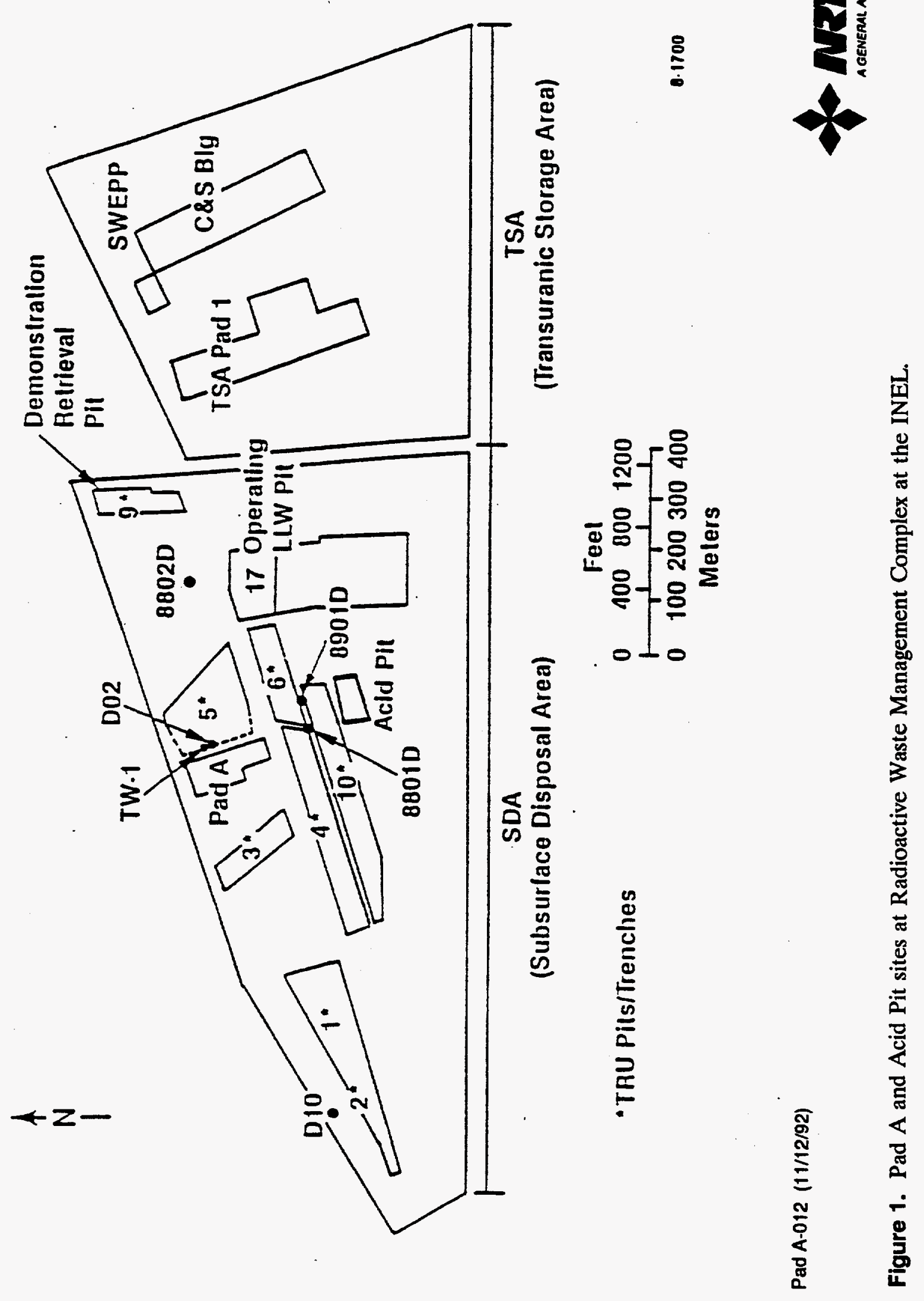


The wastes stored at Pad A consist of nitrate salts, sludges, and foundry wastes packed in drums and boxes. Approximately 4.6 million $\mathrm{kg}$, or $80 \%$ of the total volume, are salt wastes. The waste containers are stacked closely together and then covered with a $0.9-1.8 \mathrm{~m}$ layer of soil overburden. Since the initial burial, the drums and boxes have shown various stages of deterioration. Figure 2 shows how the drums and boxes are stacked together before the placement of soil overburden at Pad A in 1977. Figure 3 shows Pad A after the soil overburden was completed, and the white enclosure indicates the initial penetration area in 1989.

The salt waste consists of a homogeneous dry clumped mixture of salts and low-specific-activity nuclides. It is composed of about $90 \%$ sodium and potassium nitrate, with the balance of sodium and potassium sulfates, chlorides, and hydroxides. It may also contain trace amounts of metals such as zinc, chromium, lead, and cadmium. Shipping records indicate that the salt waste has an average TRU content of less than $1 \mathrm{nCi} / \mathrm{g}$; predominantly plutonium and americium and some uranium. ${ }^{2}$

There are over 254 million $\mathrm{kg}$ of radiologically contaminated salt wastes, nitrate compounds, stored at various DOE defense facilities as summarized in Table $1 .^{1-2}$ About 11 million $\mathrm{kg}$ of these wastes are stored at the INEL, approximately half of these are at the RWMC on Pad A.

\subsubsection{Acid Pit Contaminated Soil}

The Acid Pit contains liquid wastes that are primarily uranium-contaminated acids and chlorinated solvents generated by the INEL between 1954 and 1965 . Over 100,000 gal of liquid wastes generated by the INEL have been deposited in the pit. ${ }^{1-3}$ The liquid wastes have been neutralized amongst layers of soil and lime over time so that the pit remains generally dry.

Soils containing radionuclides and heavy metals present at other facilities are typified by those at the Acid Pit. ${ }^{3}$ Extensive borehole sampling in 1991 showed some samples with above background concentrations of U-238, Cs-137, TRU, mercury, and chromium.

Extensive borehole sampling in 1991 showed low levels of U-238 and Cs-137. Two borehole samples near the basalt base of the pit show mercury at elevated concentrations, and in one sample, chromium at above background level. Radioactive contamination in the soil is very low; one sample contains $53 \mathrm{pCi} / \mathrm{g}$ TRU and two others indicate elevated concentrations of Cs-137 and Co-60. ${ }^{1-3}$ 


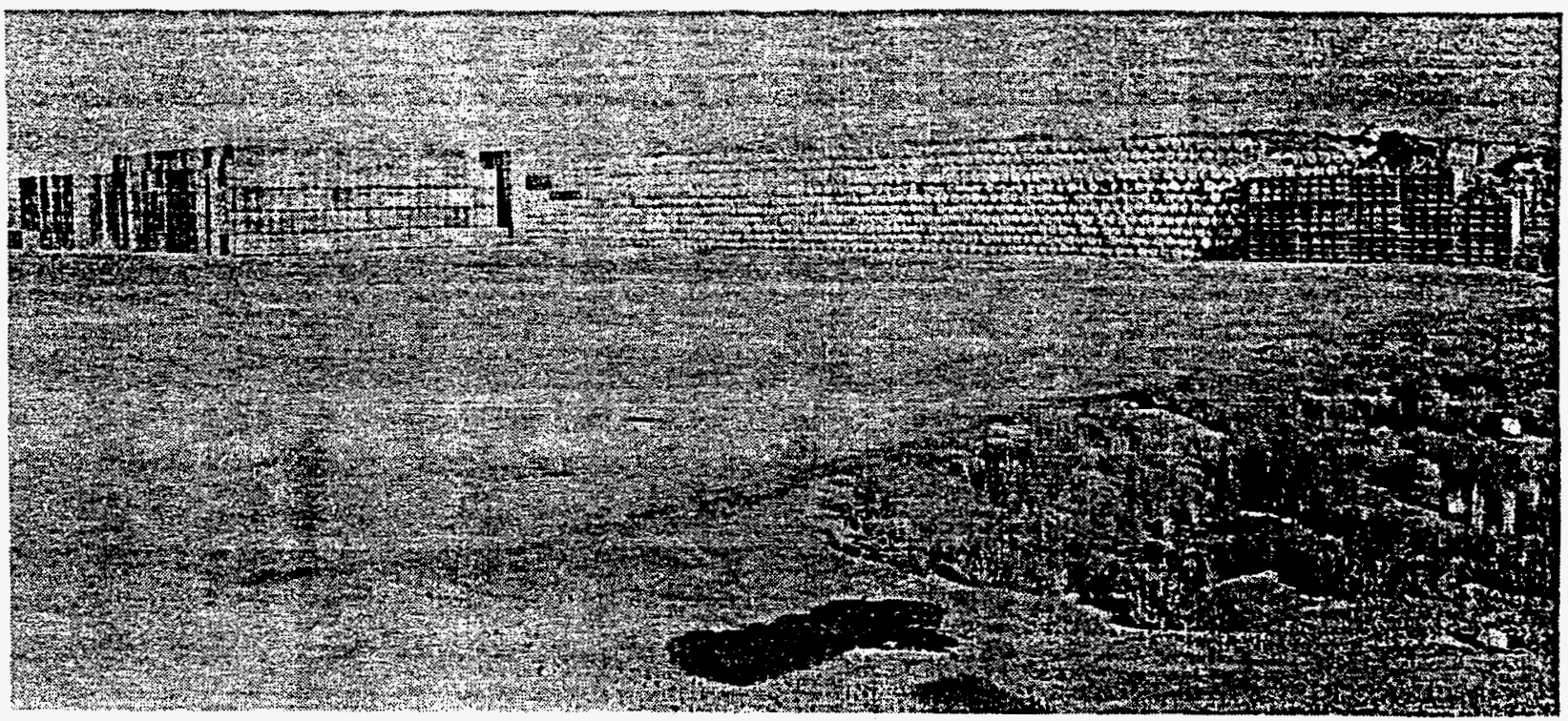

Figure 2. Pad A waste prior to closure (1977).

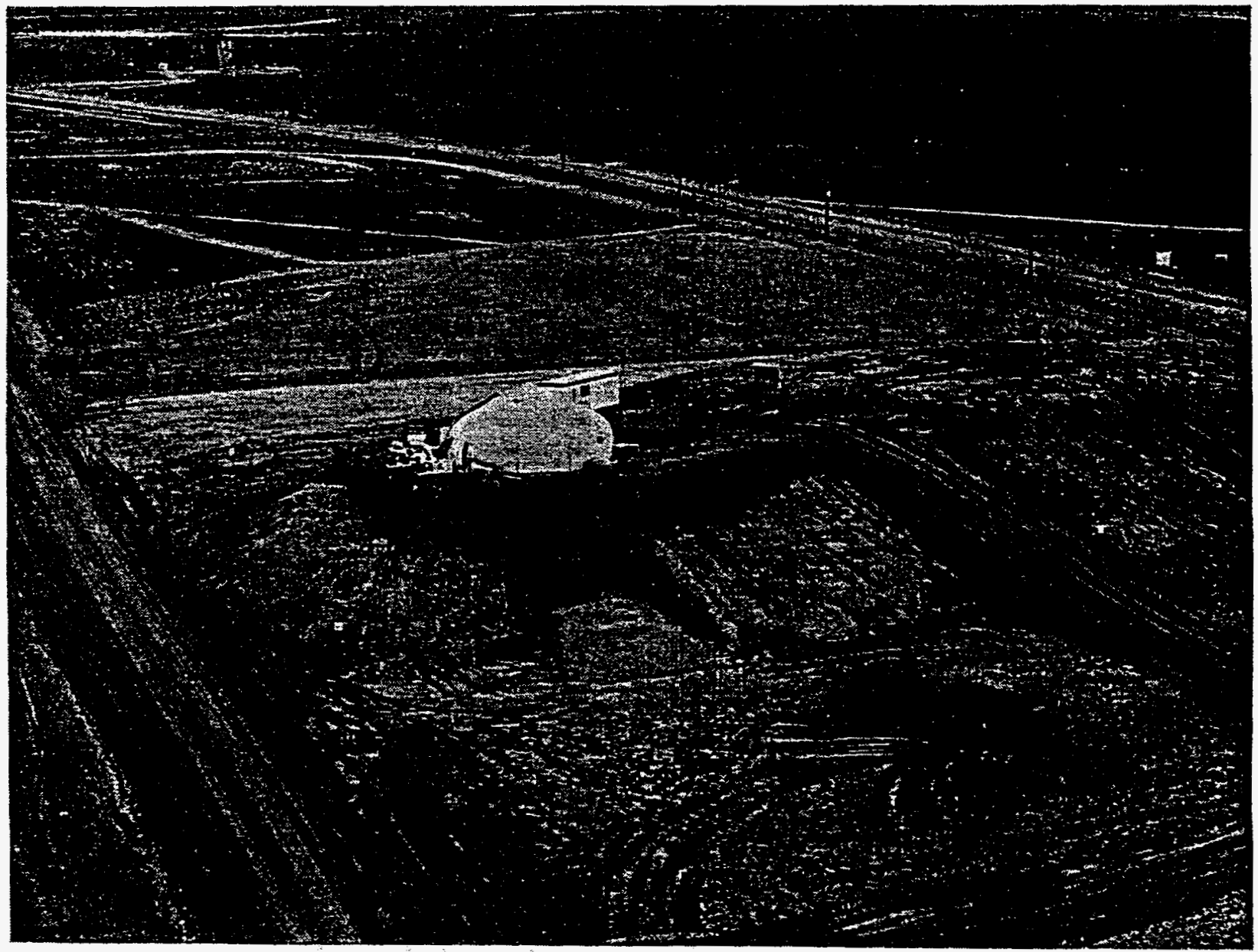

Figure 3. Pad A after closure with soil overburden (white structure shows locations of 1989 Initial Penetration Project). 
Table 1. Summary of nitrate salt waste storage and generation in defense facilities.

\begin{tabular}{|c|c|c|c|c|}
\hline Site & Type & $\begin{array}{l}\text { Amount } \\
\text { stored } \\
(\mathrm{kg})\end{array}$ & $\begin{array}{c}\text { Generation } \\
\text { rate } \\
(\mathrm{kg} / \mathrm{yr})\end{array}$ & Comments \\
\hline $\begin{array}{l}\text { Feed Materials } \\
\text { Production Center }\end{array}$ & Effluent & - & $2,200,000^{\mathrm{a}}$ & Biodenitrification planned \\
\hline Hanford-Rockwell & Effluent & - & $1,100,000^{\mathrm{a}}$ & $\begin{array}{l}\text { Discharged to ponds, } \\
\text { cribs, etc. }\end{array}$ \\
\hline Hanford-Rockwell & $\begin{array}{l}\text { Low-level } \\
\text { waste (LLW), } \\
\text { high-level } \\
\text { waste (HLW) } \\
\text { or TRU }\end{array}$ & $145,000,000^{b}$ & $1,180,000^{b}$ & Stored in tanks \\
\hline $\begin{array}{l}\text { Hanford-United } \\
\text { Nuclear }\end{array}$ & LLW & $980,000^{a}$ & $2,020,000^{a}$ & $\begin{array}{l}\text { Discharged to solar } \\
\text { ponds }\end{array}$ \\
\hline $\begin{array}{l}\text { Idaho Chemical } \\
\text { Processing Plant }\end{array}$ & HLW & $1,460,000^{2}$ & $\begin{array}{l}(24,000)^{\mathbf{a}} \\
\text { reduction }\end{array}$ & $\begin{array}{l}\text { Liquid in tanks, } \mathrm{NO}_{\mathrm{x}} \\
\text { released }\end{array}$ \\
\hline $\begin{array}{l}\text { Idaho Chemical } \\
\text { Processing Plant }\end{array}$ & HLW & $92,800^{\mathrm{a}}$ & $13,000^{a}$ & Calcine in bin sets \\
\hline $\begin{array}{l}\text { Idaho-Radioactive } \\
\text { Waste Management } \\
\text { Complex }\end{array}$ & LLW or TRU & $11,300,000^{\mathrm{b}}$ & - & Buried or stored \\
\hline $\begin{array}{l}\text { Los Alamos } \\
\text { National Laboratory }\end{array}$ & Effluent & - & $70,800^{a}$ & Discharged to canyon \\
\hline $\begin{array}{l}\text { Lawrence Livermore } \\
\text { National Laboratory }\end{array}$ & LLW & - & $<200^{\mathrm{a}}$ & $\begin{array}{l}\text { Cemented, shipped to the } \\
\text { Nevada Test Site (NTS) }\end{array}$ \\
\hline Mound Facility & LLW & - & $1,500^{c}$ & $\begin{array}{l}\text { Cemented, shipped to } \\
\text { NTS }\end{array}$ \\
\hline NTS & LLW & $10,400,000^{b}$ & - & $\begin{array}{l}\text { Received RFP salts, } \\
\text { FY78-FY85 }\end{array}$ \\
\hline $\begin{array}{l}\text { Oak Ridge } Y-12 \\
\text { Plant }\end{array}$ & Effluent & - & $664,000^{\mathrm{a}}$ & $\begin{array}{l}\text { Acid recycle } \\
\text { biodenitrification }\end{array}$ \\
\hline RFP & LLW & - & $\begin{array}{l}930,000 \text { to } \\
2,050,000^{b}\end{array}$ & $\begin{array}{l}\text { Salts/saltcrete shipped to } \\
\text { NTS }\end{array}$ \\
\hline RFP & LLW & $1,450,000^{b}$ & 一 & $\begin{array}{l}\text { Solar ponds being } \\
\text { decommissioned }\end{array}$ \\
\hline
\end{tabular}


Table 1. (continued).

\begin{tabular}{|c|c|c|c|c|}
\hline Site & Type & $\begin{array}{l}\text { Amount } \\
\text { stored } \\
\text { (kg) }\end{array}$ & $\begin{array}{c}\text { Generation } \\
\text { rate } \\
(\mathrm{kg} / \mathrm{yr})\end{array}$ & Comments \\
\hline $\begin{array}{l}\text { Savannah River } \\
\text { Plant }\end{array}$ & HLW & $82,900,000^{b}$ & $\begin{array}{l}1,480,000 \text { to } \\
2,960,000^{b}\end{array}$ & Grouting facility planned \\
\hline $\begin{array}{l}\text { The next step } \\
\text { Aerojet }\end{array}$ & LLW. & - & $38,000^{\mathrm{a}}$ & Discharged to creek \\
\hline $\begin{array}{l}\text { West Valley Pilot } \\
\text { Project }\end{array}$ & HLW & $557,000^{\mathrm{a}}$ & - & Basic waste \\
\hline $\begin{array}{l}\text { West Valley Pilot } \\
\text { Project }\end{array}$ & HLW & $73,300^{\mathrm{b}}$ & - & Acidic waste \\
\hline \multicolumn{2}{|l|}{ Total } & $254,000,000$ & \multicolumn{2}{|l|}{$\begin{array}{l}7,500,000 \text { to } \\
11,200,000\end{array}$} \\
\hline \multicolumn{5}{|c|}{ a. Based on nitrate ion. } \\
\hline \multicolumn{5}{|c|}{ b. Based on nitrate compounds. } \\
\hline \multicolumn{5}{|c|}{ c. As cemented $\mathrm{Fe}(\mathrm{OH})_{3}$ sludge. } \\
\hline
\end{tabular}




\section{LABORATORY SCALE EX SITU VITRIFICATION OF NITRATE SALTS AND SOILS}

Another objective of the effectiveness of vitrification and co-processing (destroying nitrate salts while stabilizing radiologically contaminated soil) was determined in a laboratory-scale test. The implementability and specific processing parameters, including the effectiveness of the cold-cap, will be determined in pilot-scale testing. Fixation of radiological components, while minimizing overall volume and mass, was the primary criterion for effectiveness. These tests provided salt/soil/additive compositions and operating temperatures that will be used in the pilot-scale testing.

Testing explored the range of salt-to-soil ratios and compositions that produced a durable glass product, which can be efficiently processed by a high-temperature melter, and maximize waste loading over nonwaste binders and additives. The test results will be applicable to buried wastes, residuals, and soils at the RWMC and most DOE sites as they contain nitrate salts, sludges, and contaminated soils.

Three aspects of salt/soil co-processing were studied in this testing: waste processibility, wasteform durability, and waste minimization. The first 13 melts using simulated salts and soils dealt with the processing of the salts and soil into a durable wasteform, thus minimizing foaming problems, melt viscosity, and crucible corrosions. The next 21 melts all used Pad A salt and Acid Pit soil and investigated melts maximizing durability and waste minimization. Three of these tests were performed on salt/soil mixtures spiked with lead and radionuclides. The glass product was characterized for metal content and tested with both hazardous and radioactive leach procedures. Leachates were analyzed for nitrate, metals, and radionuclide content.

Laboratory-scale vitrification yields different offgas compositions than pilot-scale testing. Nitrate salts decompose during heating, producing a melt free of these oxidizing compounds, but producing $\mathrm{NO}_{\mathrm{x}}$ (much of which passes out of the melt in gaseous form). Some of the $\mathrm{NO}_{\mathrm{x}}$ will be converted to nitrogen and oxygen as other melt constituents are oxidized. Although some chemical reduction of the $\mathrm{NO}_{x}$ to $\mathrm{N}_{2}$ occurred in the laboratory-scale tests, $\mathrm{NO}_{\mathrm{x}}$ generation could not be measured. Other corrosive and undesirable offgas constituents were not actively controlled in the laboratory-scale testing. Nitrate destruction was demonstrated in the laboratory-scale tests by measuring the nitrate content of the TCLP leachate from the glass product.

Only during pilot-scale testing in the cold-cap melter can chemical reduction of $\mathrm{NO}_{\mathrm{x}}$ in the melt be measured and the expected enhancement of the cold-cap verified. Pilot-scale testing will address minimization of $\mathrm{NO}_{x}$, halide, $\mathrm{SO}_{\mathrm{x}}$ gas production, and volatilization of metals. Retention of halides and volatile metals is also expected to be significantly enhanced in the cold-cap joule melter.

\subsection{Experimental Description}

The experimental description briefly describes the apparatus and materials used in the laboratory-scale melting. Further detail can be found in Appendix A of Reference 5. The apparatus is standard for testing formulations in the glass-making industry, while its use on actual contaminated nitrate salts and soils was unique. 


\subsubsection{Apparatus}

To attain anticipated vitrification temperatures of 1500 to $1600^{\circ} \mathrm{C}$ for testing melt mixtures, a high temperature furnace was used. The melt furnace, a modified Deltech, has working space within the melting unit (closed) of $24 \times 24 \times 28 \mathrm{~cm}$ in height and is capable of a maximum temperature of $1800^{\circ} \mathrm{C}$. A Blue $\mathrm{M}$ muffle furnace was used as an annealing oven and maintained at $660^{\circ} \mathrm{C}$ to relieve cast glass stress. Melting and cooling were performed within a Class A high-efficiency particulate air filtered the hood. A photograph of the arrangement of both furnaces is shown in Figure 4.

Crucibles used in these experiments were of the fused silica type. These crucibles are highly resistant to thermal shock and are preferred for charging of glass batches. They have a service temperature of $1600^{\circ} \mathrm{C}$. Figure 4 shows a crucible in use. Crucible volumes varied between 260-1000 $\mathrm{mL}$ depending on the desired melt size. The molten experimental glasses were cast into graphite molds kept on hot plates at about $300^{\circ} \mathrm{C}$ for more uniform casting.

\subsubsection{Waste Materials Pad A Salt and Acid Pit Soil Preparation.}

The sampling of Pad A salts and Acid Pit soil core is described in Reference 3 and Reference 5, Appendix A. Ten kilograms of composited salt from the INEL was ground using a porcelain mortar and pestle until all of the material was less than $2.38 \mathrm{~mm}$. Soil was prepared by screening out stones and pebbles greater than $1.7 \mathrm{~mm}$ and grinding the remaining portion in a Wiley mill to $0.7 \mathrm{~mm}$. The ground material was split from the batches for each melt. Selection and preparation for the testing is described in detail in Reference 5, Appendix A. A photograph of Pad A salt and ground soil are shown in Figure 5.

The elemental composition of the contaminated salt and soils used in this study for all hot melt tests are given in Table 2 and as oxides in Table 3. Nonwaste additives used were technical or reagent grade sand, limestone, boric acid, fluorspar, carbon (activated charcoal, flour, or lamp black), lead, zinc oxide, and titanium oxide. Radionuclide spike standards containing $16,050 \mathrm{pCi} / \mathrm{mL}$ of $\mathrm{Pu}-242 ; 15,922 \mathrm{pCi} / \mathrm{mL}$ of $\mathrm{Am}-241$; and $8,282 \mathrm{pCi} / \mathrm{mL}$ of $\mathrm{U}-234$ were added to three batches to raise nuclide concentrations for more challenging leach conditions.

\subsection{Experimental Procedure-High Temperature Furnace Melting of INEL Salts and Soils}

Each melt of the waste salts and soils used the same procedure. The required salt/soil/additive amounts were calculated, then raw materials were weighed and homogenized by mixing, splitting, and sieving. The batch was weighed and packed into a tared ceramic crucible. A small amount of water $(10 \mathrm{~mL})$ was added to each batch during mixing to avoid segregation when the batch was poured into the crucible. 


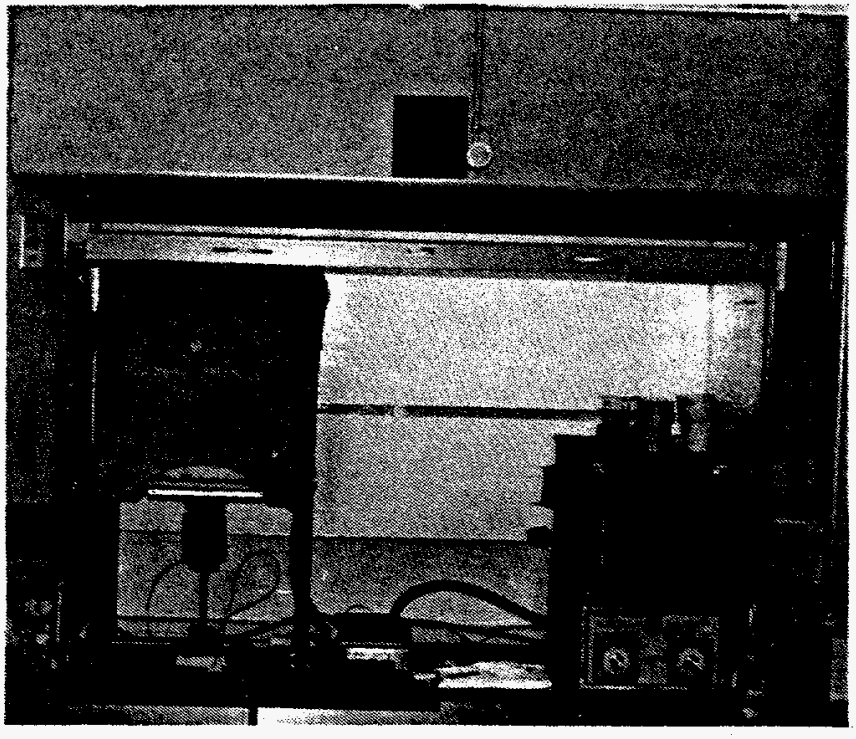

Melt furnace annealing oven inside hood

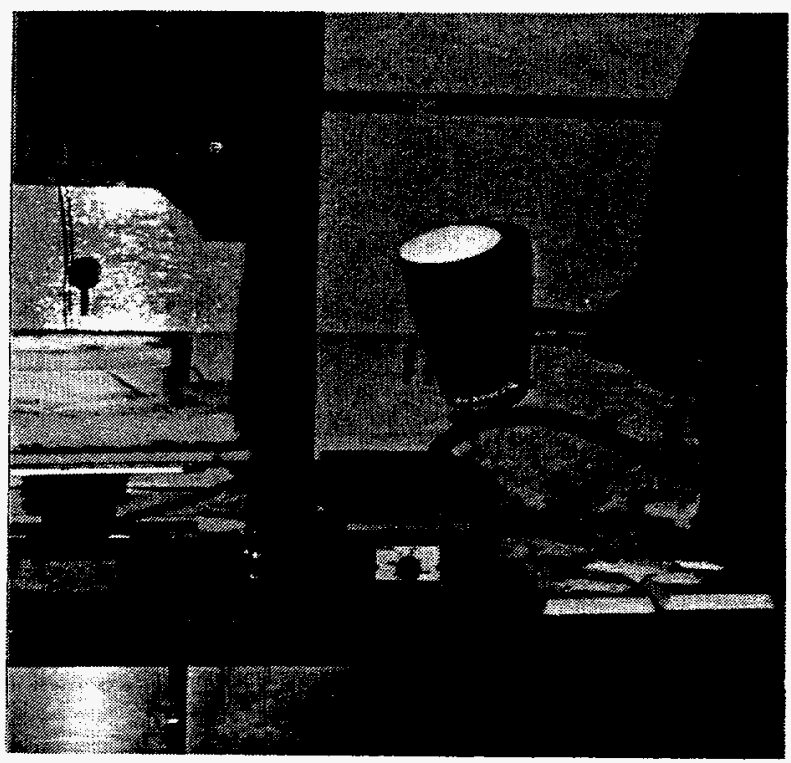

Open melt furnace, hot crucible about to be poured

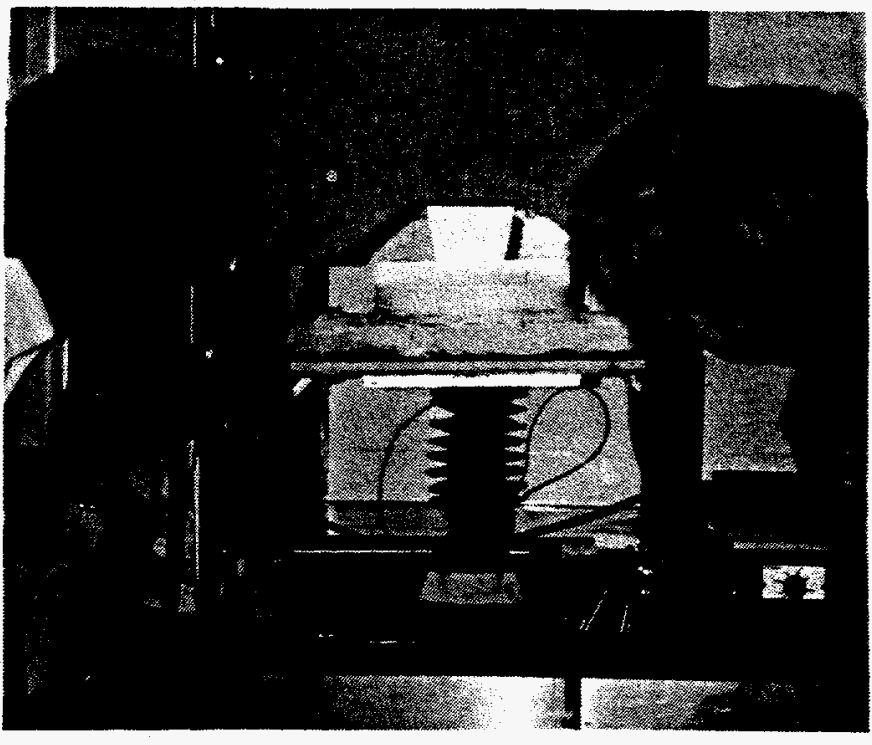

Melt furnace being opened to remove crucible

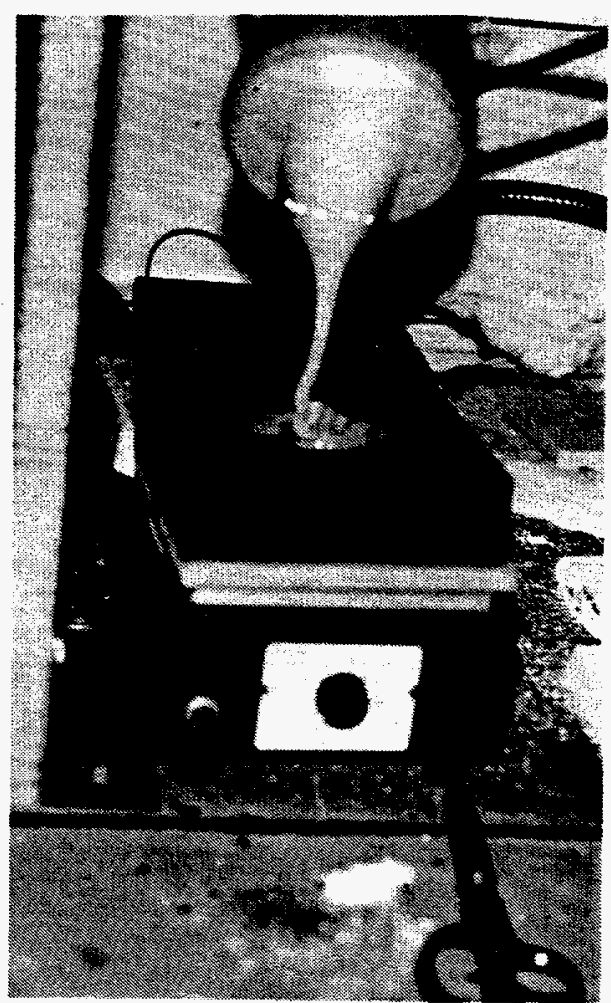

Molten glass flowing into heated graphite mold

Figure 4. Arrangements of melt furnace and annealing oven. 


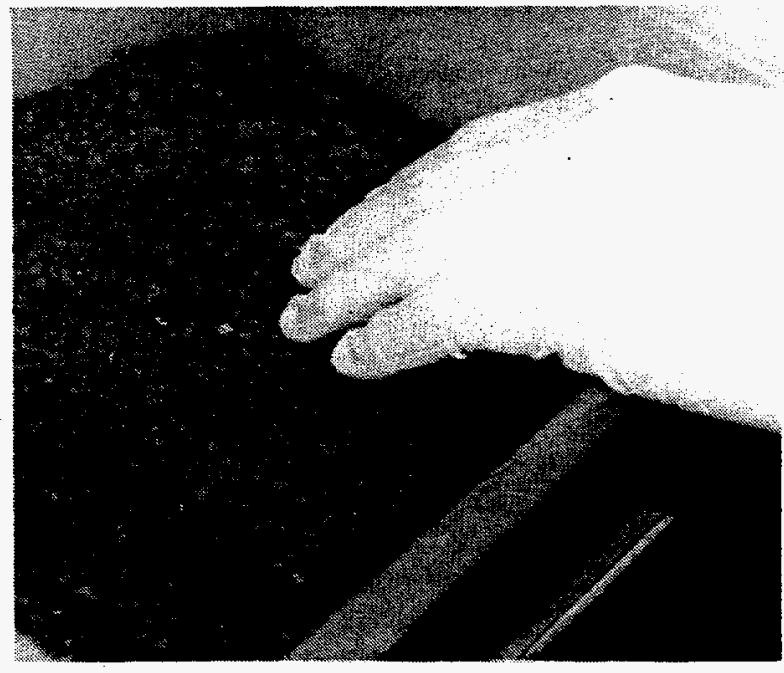

Soil as received

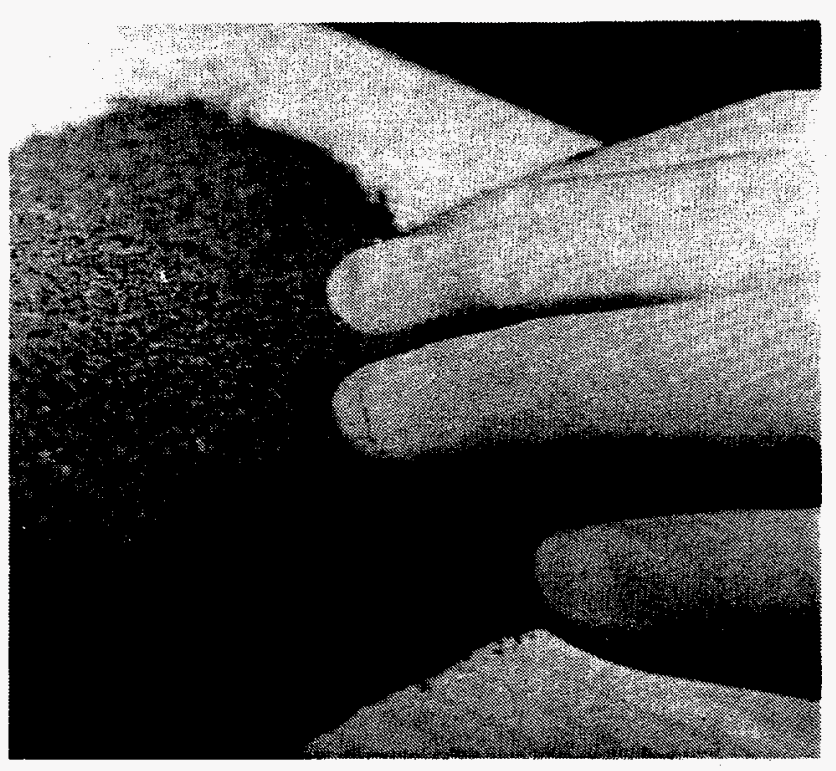

Ground soil

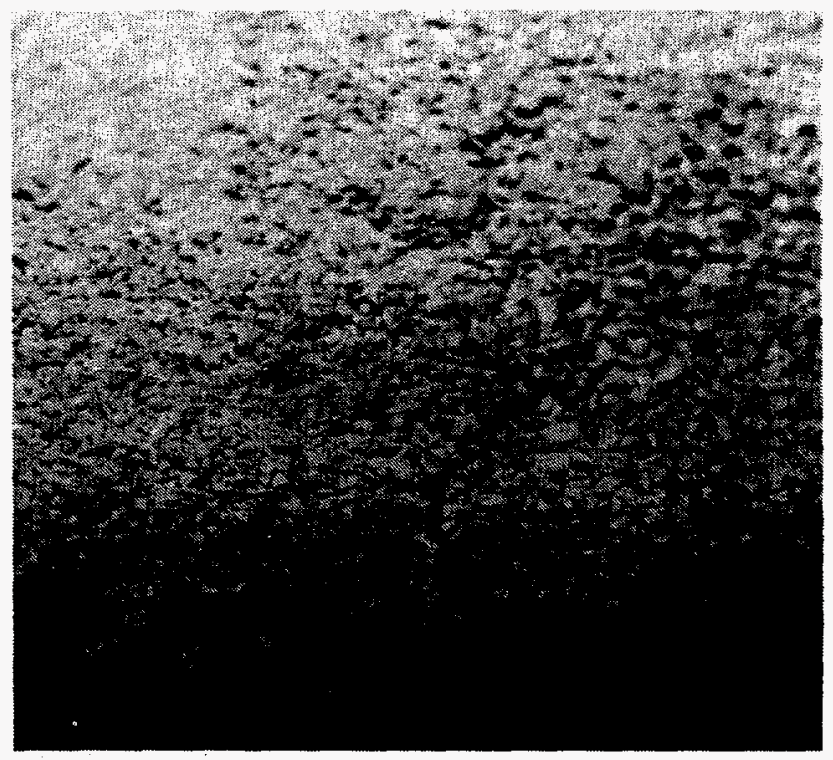

Ground salt

Figure 5. Soil and salt samples. 
Table 2. Laboratories characterizing Pad A salt, acid pit soil and glass wasteform.

MEDIA

property

INEL/RML

INEL/ECL

TCT

NRT

PNL

Pad A saits

TCLP metals -

All

All

All but $\mathrm{Pb}$

Metals

$\mathrm{Na}, \mathrm{K}, \mathrm{Fe}, \mathrm{Al}$, -

$\mathrm{Na}, \mathrm{K}$

$-$

$\mathrm{Ca}, \mathrm{Mg}$

Nonmetals

Anions, TOC Cyanide, TOX -

Radionuclides

U, Pu, Am K, -

$-$

$\mathrm{U}, \mathrm{Am}, \mathrm{K}, \mathrm{Th} \quad-$

Th, Cs

Organics

Physical

$-$

-

Semi-VOA

Moisture $\mathrm{pH} \quad-$

Density,

moisture

properties

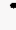

Acid Pit Soils

TCLP metals

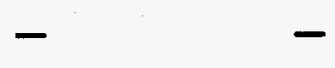

All

All but $\mathrm{Pb}$

Metals

-

Major metals

$\mathrm{Na}, \mathrm{K}$

$\mathrm{Si}, \mathrm{Al}, \mathrm{Ca}$ $\mathrm{Fe}, \mathrm{Mg}$,

$\mathrm{Na}$

Nonmetals

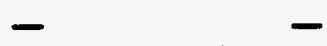

Anions

Radionuclides

$\mathrm{U}, \mathrm{Am}, \mathrm{K}$ Th

-

Organics

Physical

properties

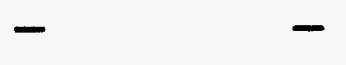

Prior pollut.

Moisture

density

Glass wasteform

TCLP metals

$-$

$-$

-

$\mathrm{Cr}, \mathrm{Pb}$,

$\mathrm{Ba}, \mathrm{Cd}$

Metals

-

-

$\mathrm{Na}, \mathrm{K}$

Major

metals

Radionuclides

$\mathrm{U}, \mathrm{Ce}, \mathrm{Pu}$,

$-$

Am, U, K, Th - 
Table 2. (continued).

\begin{tabular}{llllll}
\hline $\begin{array}{l}\text { MEDIA } \\
\text { property }\end{array}$ & INEL/RML & INEL/ECL & TCT & NRT & PNL \\
\hline Leachates & - & - & - & $\begin{array}{l}\text { TCLP, } \mathrm{NO}_{3}, \\
\text { gross alpha }\end{array}$ & $\begin{array}{l}\mathrm{Cr}, \mathrm{Pb}, \\
\mathrm{Ba}, \mathrm{Cd}\end{array}$ \\
$\begin{array}{l}\text { Physical } \\
\text { properties }\end{array}$ & - & - & Density & - \\
\hline RML - Radiations Measurements Laboratory & NRT - Nuclear Remediation Technology & \\
ECL - Environmental Chemistry Laboratory & PNL - Pacific Northwest Laboratory & \\
TCT - Tri Cities Testing & & & & \\
\hline
\end{tabular}


Table 3. Oxide composition of Pad A salt, Acid Pit soil, and a final glass wasteform.

Weight percent

\begin{tabular}{lccc}
\cline { 2 - 3 } \multicolumn{1}{c}{$\begin{array}{c}\text { Metallic } \\
\text { oxide }\end{array}$} & $\begin{array}{c}\text { Pad A } \\
\text { salt }\end{array}$ & $\begin{array}{c}\text { Acid Pit } \\
\text { soil }\end{array}$ & $\begin{array}{c}\text { Wasteform } \\
(35 \%)\end{array}$ \\
\hline $\mathrm{SiO}_{2}$ & 0.07 & 70.6 & 53.3 \\
$\mathrm{Al}_{2} \mathrm{O}_{3}$ & 0.02 & 9.1 & 7.5 \\
$\mathrm{Na}_{2} \mathrm{O}$ & 32.3 & 1.9 & 14.7 \\
$\mathrm{~K}_{2} \mathrm{O}$ & 10.3 & 2.7 & 6.4 \\
$\mathrm{CaO}$ & 0.5 & 2.3 & 6.5 \\
$\mathrm{Fe}_{2} \mathrm{O}_{3}$ & 0.06 & 1.9 & 1.7 \\
$\mathrm{MgO}$ & 0.002 & 1.0 & 0.6 \\
$\mathrm{Cr}_{2} \mathrm{O}_{3}$ & 0.05 & 0.01 & 0.03 \\
$\mathrm{U}_{3} \mathrm{O}_{8}$ & 0.04 & 0.03 & 0.03 \\
$\mathrm{P}_{2} \mathrm{O}_{5}$ & 1.0 & 0.15 & 0.4 \\
$\mathrm{BaO}$ & 0.02 & 0.14 & 0.05 \\
$\mathrm{Total}_{2}$ & & & 91.2 \\
\hline
\end{tabular}

The melt furnace was heated to $1500-1575^{\circ} \mathrm{C}$, opened, and the crucible inserted. Each batch was held in the furnace for about 60 minutes. The crucible was then removed from the furnace, and the molten glass poured into a graphite mold. During pouring, glass viscosity was estimated by eye. The color, presence of a separate metallic phase, or other inhomogeneities were noted. Each piece of poured glass was allowed to solidify in the mold for about 5 minutes before it was transferred to the annealing furnace at $660^{\circ} \mathrm{C}$ for at least one half hour, then cooled slowly.

The cooled glass was weighed, viewed under the microscope, photographed, and archived. To provide data for glass density calculation, a piece from each of the glass pours was weighed separately and its volume measured by displacement of sand. Because the inside of each crucible was coated with glass after pouring, the weight of the crucible was also determined to allow calculation of the percent of the glass that poured out of the crucible. The appearance of the crucible was observed, noting the presence of corrosion, foamover, slag, or a separate metallic phase.

Compatibility of candidate electrode materials, molybdenum, chromium, and graphite was tested during a glass melt of medium (0.43) salt-to-soil ratio and $21 \%$ alkali. Candidate electrode material coupons were measured, weighed, and covered by the placed raw material mix in the crucibles. The 
sources and compositional specifications for each of the corrosion test coupons is summarized in Reference 5, Appendix A. Photos of the test coupons are shown in Figure 6. The batches were melted at $1500^{\circ} \mathrm{C}$ for 4 hours, maintained at $1000^{\circ} \mathrm{C}$ for 13 hours, raised to $1500^{\circ} \mathrm{C}$ for an additional 4 hours, and removed from the furnace, annealed, and cooled. The coupons were cleaned, weighed, measured, and described visually as to the physical condition of the coupons. Molybdenum was more resistant than chrome with no apparent corrosion or corrosion related weight loss. Graphite electrodes completely oxidized and no conclusions are possible because of inappropriate test conditions. Full details of the raw material weights and estimated glass compositions are found in Tables 6-3 and 6-4 in Appendix A of Reference 5.

\subsubsection{Experimental Summary.}

Thirty-four melts were performed, 13 with simulated ingredients and 21 with actual contaminated salts and soils. A summary of these is provided in Table 4. Six melts were not poured. Twenty melts had silicon oxide content between 60 and $66 \%$ near that desired for a normal glass of $65-70 \mathrm{wt} \%$. Seven melts had silicon oxide contents below $55 \mathrm{wt} \%$. Four of these had alkali contents from actual waste higher than $25 \%$, ranging from 25.5 to 43.65 . Figure 7 shows glass cast with this composition.

Nine melts were made with actual waste, salt-to-soil ratios of 0.4 to 0.5 and final silica contents of approximately $60-63 \%$. In some of these additional sand was added to increase the silica content above $60 \%$. Various fluxing agents were used to achieve appropriate melt viscosities. Boric acid was used as a flux in seven tests since the boron oxide remaining in the glass also tends to increase glass durability. Five of these melts also had added calcium and silicon forming borosilicate glasses. The salt-to-soil ratio for these ranged from 0.47 to 0.25 . Five tests were formulated with durability-enhancing alkaline earth additives; no boron and higher salt loadings (greater than 25\%) were used. Figure 8 shows glass cast from such a melt.

\subsubsection{Characterization and Wasteform Leach Testing}

Two types of leach testing were performed: EPA Method 1311 TCLP tests on lead and transuranic spiked glass samples and Nuclear Regulatory Commission (NRC) Product Characterization Test (PCT) leach tests on glass forms with a wide range of alkali contents. Glass samples were crushed for leach testing. A particle size of $<9.5 \mathrm{~mm}$ is required for the TCLP and $<0.2 \mathrm{~mm}$ for the PCT. Room temperature was used for 24-hour TCLP leaching, and the temperature was raised to $90^{\circ} \mathrm{C}$ for 7 days in the PCT. The TCLP method requires a high pH sodium acetate leach solution, and the PCT uses distilled water. The TCLP is concerned with the short-term leaching of eight selected toxic metals. The PCT tests longer term breakdown of the wasteform measuring the structural metals in solution over time.

Three wasteforms, two with high alkali (nitrate salts) and one with high alkaline (calcium) were used for TCLP leach testing. These were spiked with lead shavings of uranium, plutonium, and americium containing solutions providing a higher source concentration than is found in the waste salts and soils. A fourth wasteform, with surrogate salt and soil, was used as a blank for the 

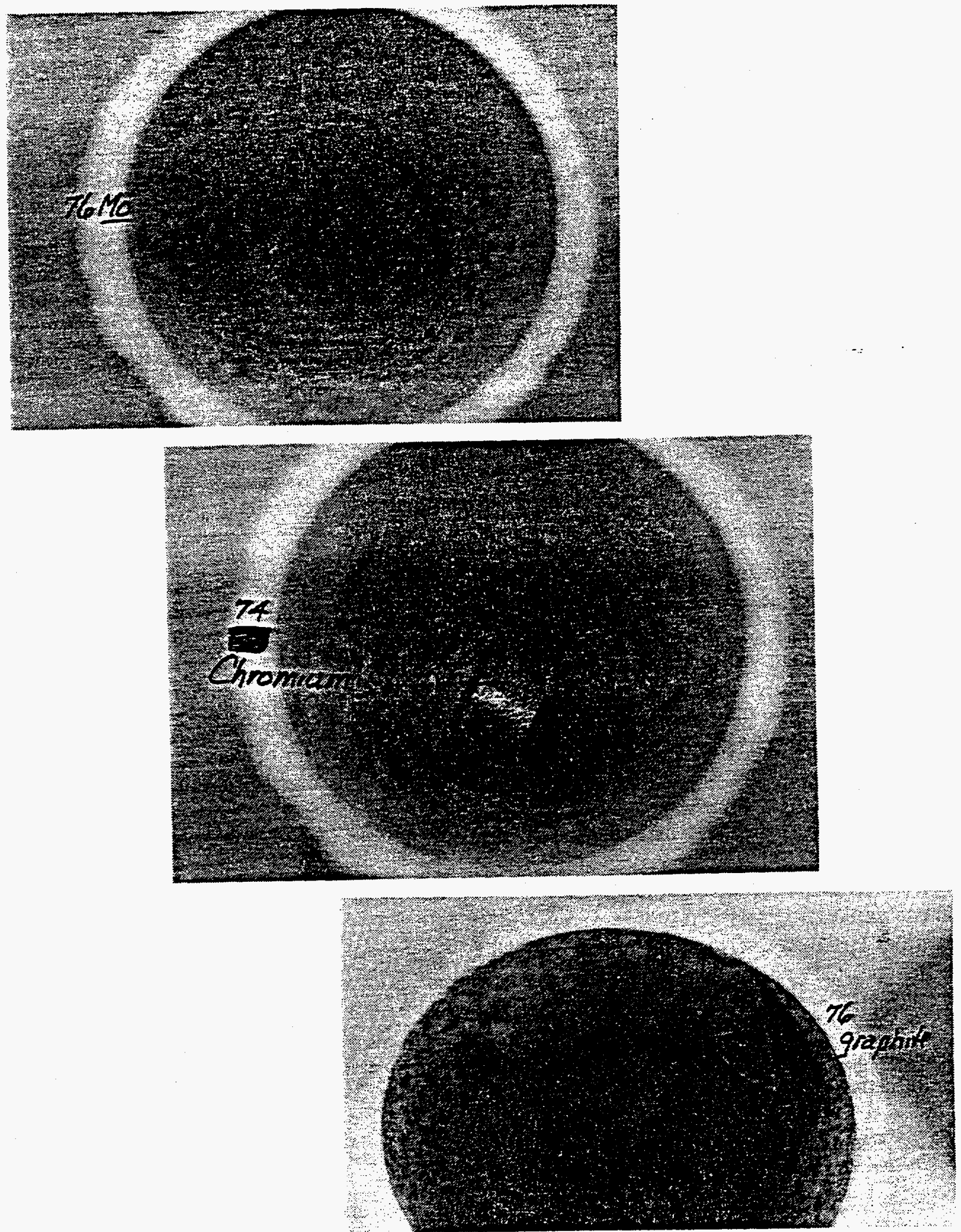

Figure 6. Electrode materials to be used in corrosion tests. 
Table 4. Laboratory testing summary.

\begin{tabular}{|c|c|c|c|}
\hline $\begin{array}{l}\text { General } \\
\text { composition }\end{array}$ & $\begin{array}{c}\text { Glass } \\
\text { characteristic }\end{array}$ & Test purpose & $\begin{array}{l}\text { Number } \\
\text { of } \\
\text { melts }\end{array}$ \\
\hline $\begin{array}{l}\text { Pad A salt, Acid Pit soil and } \\
\text { additives }\end{array}$ & $\begin{array}{l}\text { Testing of actual } \\
\text { INEL salts and soil }\end{array}$ & - & 21 \\
\hline $\begin{array}{l}\text { Pad A salt and Acid Pit soil, } \\
\text { carbon }\end{array}$ & $\begin{array}{l}\text { Very high alkali } \\
>35 \%\end{array}$ & Waste minimization & 3 \\
\hline $\begin{array}{l}\text { Pad A salt and Acid Pit soil, } \\
\text { carbon }\end{array}$ & High alkali $>25 \%$ & Waste minimization & 4 \\
\hline $\begin{array}{l}\text { Pad A salt and Acid Pit soil, } \\
\text { carbon }\end{array}$ & $\begin{array}{l}\text { Salt/soil ratio } 0.43 \\
\text { alkali } 20-21 \%\end{array}$ & $\begin{array}{l}\text { Waste processing quality } \\
\text { control }\end{array}$ & 9 \\
\hline $\begin{array}{l}\text { Pad A salt and Acid Pit soil, } \\
\text { carbon, boron }\end{array}$ & Borosilicate glass & Wasteform durability & 7 \\
\hline $\begin{array}{l}\text { Pad A salt and Acid Pit soil, } \\
\text { carbon, sand, limestone }\end{array}$ & $\begin{array}{l}\text { Higher silica, alkaline } \\
\text { earth glass }\end{array}$ & Wasteform durability & 5 \\
\hline $\begin{array}{l}\text { Pad A salt and Acid Pit soil, } \\
\text { carbon, limestone }\end{array}$ & $\begin{array}{l}\text { High alkaline earth } \\
>10 \%\end{array}$ & Waste processing & 2 \\
\hline $\begin{array}{l}\text { Pad A salt and Acid Pit soil, } \\
\text { carbon, lead, } \mathrm{Pu}, \mathrm{U}, \mathrm{Am}\end{array}$ & $\begin{array}{l}\text { Glass spiked with lead } \\
\text { and Pu-242, U-234, } \\
\text { Am-241 }\end{array}$ & Wasteform durability & 3 \\
\hline Surrogate salt and soil & Test set up & & 13 \\
\hline $\begin{array}{l}\text { Simulated salt and soil, carbon, } \\
\text { sand, limestone }\end{array}$ & $\begin{array}{l}\text { Sodium, boro-silicate } \\
\text { glass, scoping }\end{array}$ & $\begin{array}{l}\text { Waste processing quality } \\
\text { control }\end{array}$ & 5 \\
\hline $\begin{array}{l}\text { Simulated salt, INEL soil, } \\
\text { carbon, sand }\end{array}$ & $\begin{array}{l}\text { Iron enriched basalt } \\
\text { (IEB)/glass, scoping } \\
\text { formulations }\end{array}$ & $\begin{array}{l}\text { Waste processing quality } \\
\text { control }\end{array}$ & 8 \\
\hline $\begin{array}{l}\text { Both simulate and actual salts } \\
\text { and soils }\end{array}$ & $\begin{array}{l}\text { Duplicate hot and } \\
\text { cold formulation }\end{array}$ & Quality control & 6 \\
\hline $\begin{array}{l}\text { Pad A salt and Acid Pit soil, } \\
\text { carbon }\end{array}$ & $\begin{array}{l}\text { Duplicate hot } \\
\text { formulations }\end{array}$ & Quality control & 6 \\
\hline $\begin{array}{l}\text { Both simulate and actual salts } \\
\text { and soils }\end{array}$ & Triplicates & Quality control & 6 \\
\hline $\begin{array}{l}\text { Pad A salt and Acid Pit soil, } \\
\text { carbon }\end{array}$ & $\begin{array}{l}\text { Electrode material } \\
\text { coupon corrosion }\end{array}$ & Waste processing & 2 \\
\hline
\end{tabular}




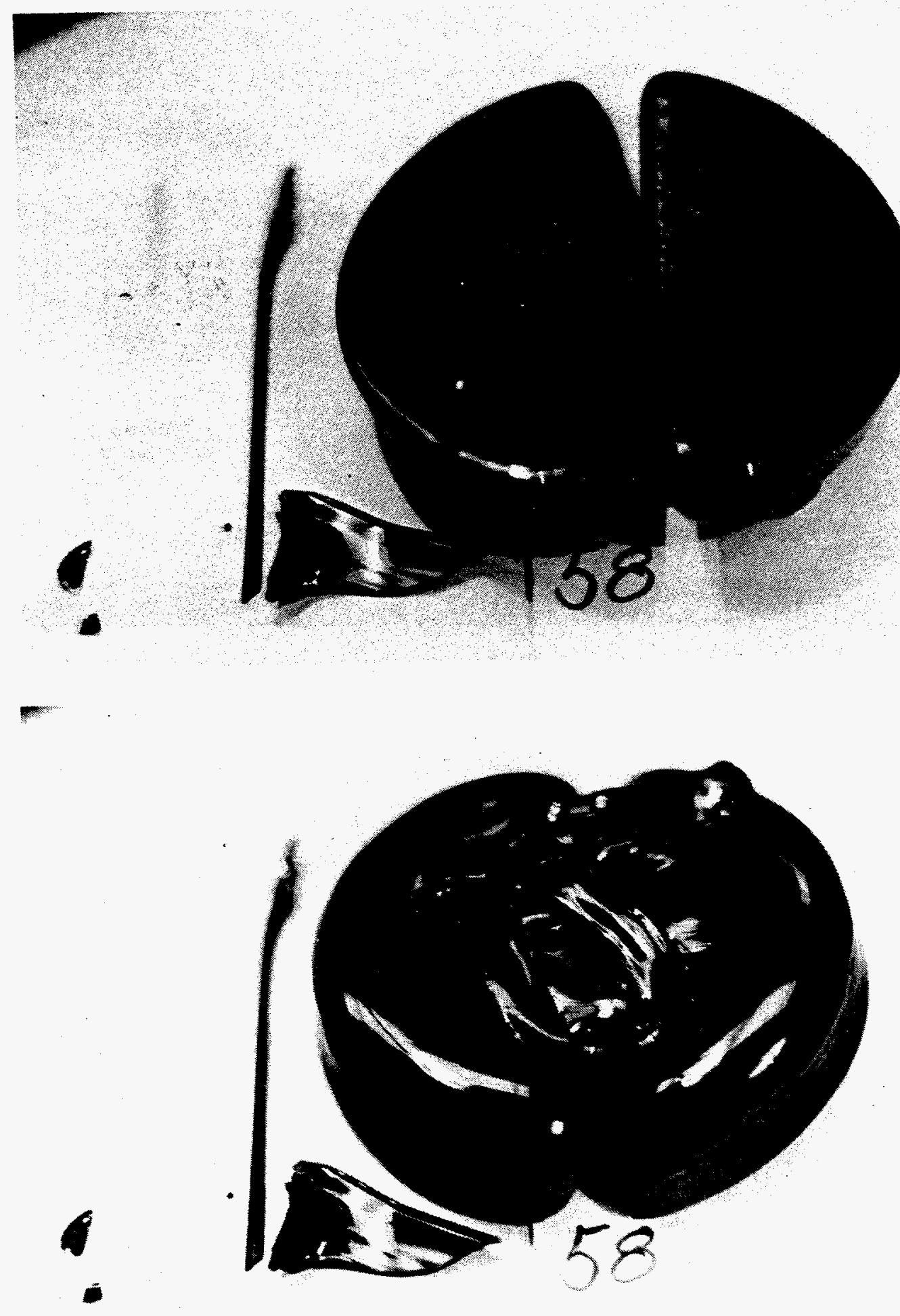

Figure 7. Glass cast from Melt \#58. 


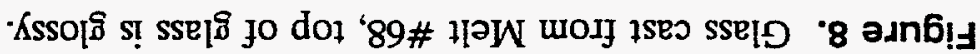
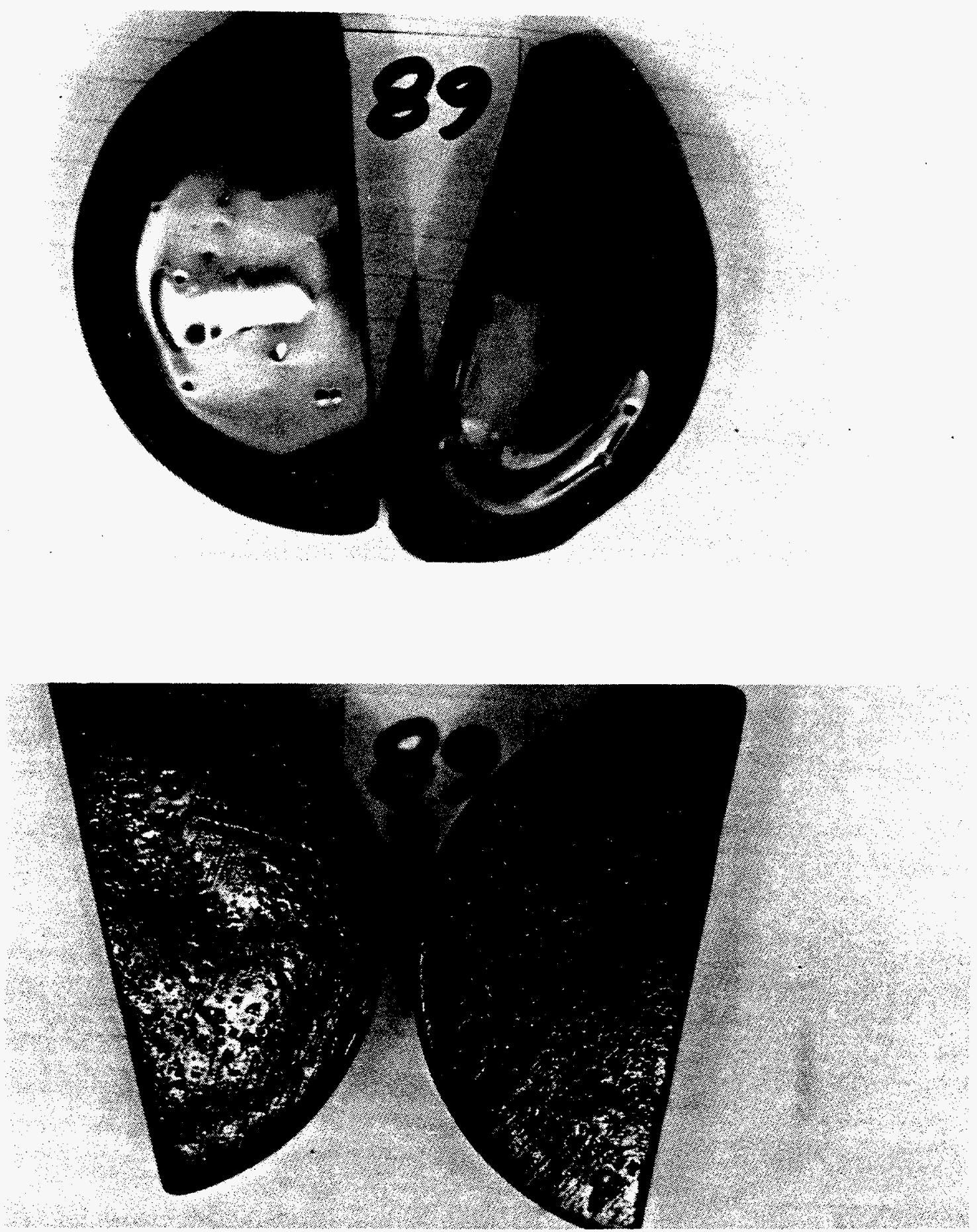
radionuclide measurements. Leachate was measured for the eight TCLP toxic metals, potassium, nitrates, and radionuclides. The glass wasteform was analyzed for all seven EPA toxic metals, potassium, and gamma emitting radionuclides.

Six wasteforms, with alkali contents ranging from 17 to $39 \%$ were tested with the PCT leach test. The wasteform and leachate were measured for matrix elements such as silicon, aluminum, sodium, potassium, and calcium. This test does not have the pass fail limits of the TCLP, but does allow a long-term assessment of the wasteform to be estimated.

\subsection{Waste and Wasteform Analysis}

Thirty-four glass wasteforms were prepared using the above procedure melting ingredients together at $1525-1575^{\circ} \mathrm{C}$. Thirteen glass samples were prepared with surrogate salts and sand or INEL soil and 21 prepared from actual Pad A salts (15 to $50 \mathrm{wt} \%$ ) and Acid Pit soils (40 to 80 wt\%). Ten of these were leach tested. Six high alkali (40 to $60 \%$ salt, 22 to $39 \%$ alkali) and 19 glasses of a normally more durable type (6\% boron oxide, 5 to $15 \%$ calcium oxide, or $65-70 \%$ silicon oxide) were produced.

Analytical data for the salt, soil, and glass wasteforms were obtained from sources listed in Table 2. NRT did the preparation of waste sampling, TCLP leach testing and nondestructive salt, soil, and glass analysis. Tri Cities Testing (TCT) St. Louis-Chemical Laboratory did the salt and soil analysis, the Pacific Northwest Laboratory (PNL) did the elemental analysis and PCT of the glasses. The INEL Radiations Measurements Laboratory (RML) did both alpha and gamma analysis of the salts and glasses. The INEL Environmental Chemistry Laboratory (ECL) did the salt analysis for metals, TCLP metals, and anions.

Characterization of salts, soils, wasteforms, and leachates was completed by a variety of techniques. Atomic absorption (AA) was used for mercury, potassium, lead and sodium. Inductively coupled plasma-atomic emission spectrometry (ICP-AES) was used for all metals both structural and toxic, except mercury. Instrumental Neutron Activation Analysis (INAA) was used for potassium, sodium, and EPA toxic metals, except lead. Anion concentrations in the soluble portion of the salts and soils and in verifying destruction of nitrate was done by ion chromatography. Gravimetric determinations include waste and wasteform, volume, mass, density, and moisture. These results are used to determine waste minimization. The analysis methods for all these techniques are summarized in Appendix A of Reference 5.

Organic analysis was done on the Acid Pit's soil and the Pad A salts. Total organic carbon and total organic halide content in the salts were determined by specific analysis for these species on dilute salt solutions. Semi-volatile organics were determined after acidic methylene chloride extraction by gas chromatography-mass spectrometry. Salts were also analyzed colorimetrically for surfactants (soaps), cyanides and $\mathrm{Cr}^{+6}$. The organic content of the soil was not directly determined but estimated from Loss on Ignition at $600^{\circ} \mathrm{C}$. The organic content of the glass was assumed to be essentially zero with even the inorganic carbonate lost as $\mathrm{CO}_{2}$. In the pilot test, the cold-cap is expected to enable the processing of organics in the waste enhancing reaction to $\mathrm{CO}_{2}$ before offgas.

Salt samples were obtained from representative composites of a retrieved Pad A drum. Salt formation and sampling details are given in Appendix A of Reference 5. The salt originated from 
dried decontaminated chemical process water. A single Pad A salt drum was sampled and composited to provide all salt samples used in the test. The salt was analyzed primarily in solution though nondestructive solid analysis by INAA was performed.

Samples of Acid Pit soils have been extensively characterized. ${ }^{3}$ The soil was from corings taken during characterization of the INEL Acid Pit area. The core selected had a gamma activity above background. A representative soil sample from this core used in the test was characterized nondestructively by gamma spectroscopy and INAA. Lead concentration was determined by AA. Bulk density and moisture content were determined by gravimetry.

Glass wasteform samples were obtained by fracturing the glass after annealing and cooling. The glass had to be warmed and dipped in liquid nitrogen to safely break-off chunks. Three laboratories characterized glass samples from 10 melts, chemically, radiochemically, and by leach testing (TCLP and PCT). Three glass wasteforms spiked with radiological and chemically hazardous metals were chemically, radiochemically, and leach tested with the TCLP. The glass wasteforms tested had a wide range of alkali content $17-39 \%$. The glass wasteforms were similar to a high sodium form of IEB.

Characterization analysis results for Pad A nitrate salt, Acid Pit soil, and the final glass wasteform after melting are given in Tables 3 and 5 through 7 . The tables list the results of the extensive analysis performed on waste used and wasteforms formed in the laboratory melt testing described above. Extensive Acid Pit soil analyses was done in a site characterization program described in Reference 2. The salt composition had been estimated from inventory and chemical process records.

Soil similar to what was used was analyzed destructively by ICP and AA and nondestructively by $x$-ray fluorescence and the soil used was analyzed for a limited number of metals by INAA. Elemental analyses for both EPA toxic and structural metals at three different laboratories were performed from the batch actually used in the testing. Three homogenized Acid Pit soil samples were characterized by three labs. These samples were from cores above and belowground and the one actually used in testing.

Toxic metal composition of salts and soils reveals metals that might exceed the leachable limits of the TCLP. They are (a) chromium, (b) barium, (c) lead, and (d) mercury. The high chrome content may be related to the high cyanide (that is most of the chrome is complexed) holding it in solution even at the high $\mathrm{pH}$. The concentrations of EPA toxic metals in the soil are typical for INEL soils values; except mercury in some samples. Other soils sampled in the Acid Pit reveal even higher concentrations of these metals most likely coming from the acid waste neutralized in the pit. The proposed technology will incorporate most of the EPA toxic metals in the glass; however no high temperature process can incorporate mercury. The removal of mercury in the offgas system and success of incorporating arsenic and selenium in the glass, can only be tested in the pilot-scale joule melter unit with a cold-cap and offgas system. 
Table 5. Elemental composition of Pad A salt, acid pit soil, and a final glass wasteform.

Concentration

(ppm)

\begin{tabular}{llll}
\cline { 2 - 4 } \multicolumn{1}{c}{ Element } & \multicolumn{1}{c}{ Pad A Salt } & \multicolumn{1}{c}{ Acid Pit Soil } & \multicolumn{1}{c}{$\begin{array}{c}\text { Vitrified } \\
\text { wasteform } \\
(35 \% \text { salt })\end{array}$} \\
\hline Arsenic & $0.74 \pm 6 \%^{\mathrm{h}}$ & $<9.2^{\mathrm{a}}$ & $<7^{\mathrm{a}}$ \\
Barium & $4.6 \pm 14 \%^{\mathrm{h}}$ & $1315 \pm 25 \%^{\mathrm{b}}$ & $490^{\mathrm{a}}$ \\
Cadmium & $<1^{\mathrm{h}}$ & $<4.6^{\mathrm{a}}$ & $<22^{\mathrm{a}}$ \\
Chromium & $404 \pm 32 \%^{\mathrm{c}}$ & $39 \pm 25 \%^{\mathrm{b}}$ & $180 \pm 4 \%^{\mathrm{a}}$ \\
Mercury & $0.04 \pm 40 \%^{\mathrm{h}}$ & $18^{\mathrm{a}}$ & $<1^{\mathrm{a}}$ \\
Selenium & $<0.2^{\mathrm{h}}$ & $<2.8^{\mathrm{d}}$ & $<3^{\mathrm{a}}$ \\
Silver & $<0.2^{\mathrm{h}}$ & $<2.2^{\mathrm{d}}$ & $<2^{\mathrm{a}}$ \\
Lead & $1.3 \pm 27 \%^{\mathrm{h}}$ & $20^{\mathrm{b}}$ & $<1000(11500)^{\mathrm{e}}$ \\
Aluminum & $880 \pm 4 \%^{\mathrm{d}}$ & $53,600 \pm 4 \%^{\mathrm{b}, \mathrm{c}}$ & $44,700 \pm 4 \%$ \\
Calcium & $2,610 \pm 13 \% \%^{\mathrm{d}}$ & $1,740 \pm 4 \% \%^{\mathrm{b}, \mathrm{c}}$ & $8,130 \pm 10 \%$ \\
Iron & $640^{\mathrm{f}}$ & $16,900 \pm 3 \%^{\mathrm{b}, \mathrm{c}}$ & $14,900 \pm 18 \%^{\mathrm{e}}$ \\
Lithium & $1,000^{\mathrm{f}}$ & $\mathrm{NA}$ & $\mathrm{NA}$ \\
Magnesium & $20^{\mathrm{f}}$ & $6,600 \pm 25^{\mathrm{b}}$ & $4,200 \pm 37 \%^{\mathrm{e}}$ \\
Potassium & $75,600^{\mathrm{a}} \pm 24 \%$ & $20,400 \pm 14 \%^{\mathrm{a}}$ & $47,000 \pm 18 \%^{\mathrm{a}}$ \\
Silicon & $340^{\mathrm{f}}$ & $330,000 \pm 3 \%^{\mathrm{b}, \mathrm{c}}$ & $249,000 \pm 3 \%^{\mathrm{e}}$ \\
Sodium & $200,000^{\mathrm{a}} \pm 0.5 \%$ & $10,300 \pm 0.5 \%^{\mathrm{a}}$ & $91,300 \pm 0.5 \% \%^{\mathrm{a}}$ \\
Total metal & 282,000 & 441,000 & 461,000
\end{tabular}

a. Neutron Activation Analysis (NAA) on actual Pad A salt, Acid Pit soil, and wasteform from test; uncertainty is analytical counting.

b. Inductively Coupled Plasma (ICP) analysis on a similar soil adjacent to the core section used in test; uncertainty includes analytical and sample inhomogeneity.

c. ICP and NAA analysis on actual salt used in test; uncertainty is analytical and sampling.

d. NAA on actual Pad A salt and an adjacent soil; uncertainty includes analytical and sample inhomogeneity.

e. ICP analysis of $28 \%$ salt wasteform, parenthesis indicates the final spiked lead concentration, uncertainty is analytical and sampling.

f. Atomic absorption (AA) and emission spectrometry on a grab sample from solution (36\%) feed to salt drying; uncertainty unknown.

g. NA $=$ Not attempted.

h. ICP or AA on a single composite salt sample in $3 \%$ solution, uncertainty is analytical only from spike and duplicate variations. 
Table 6. Nonmetal composition of Pad A salt, Acid Pit soil, and a final glass wasteform.

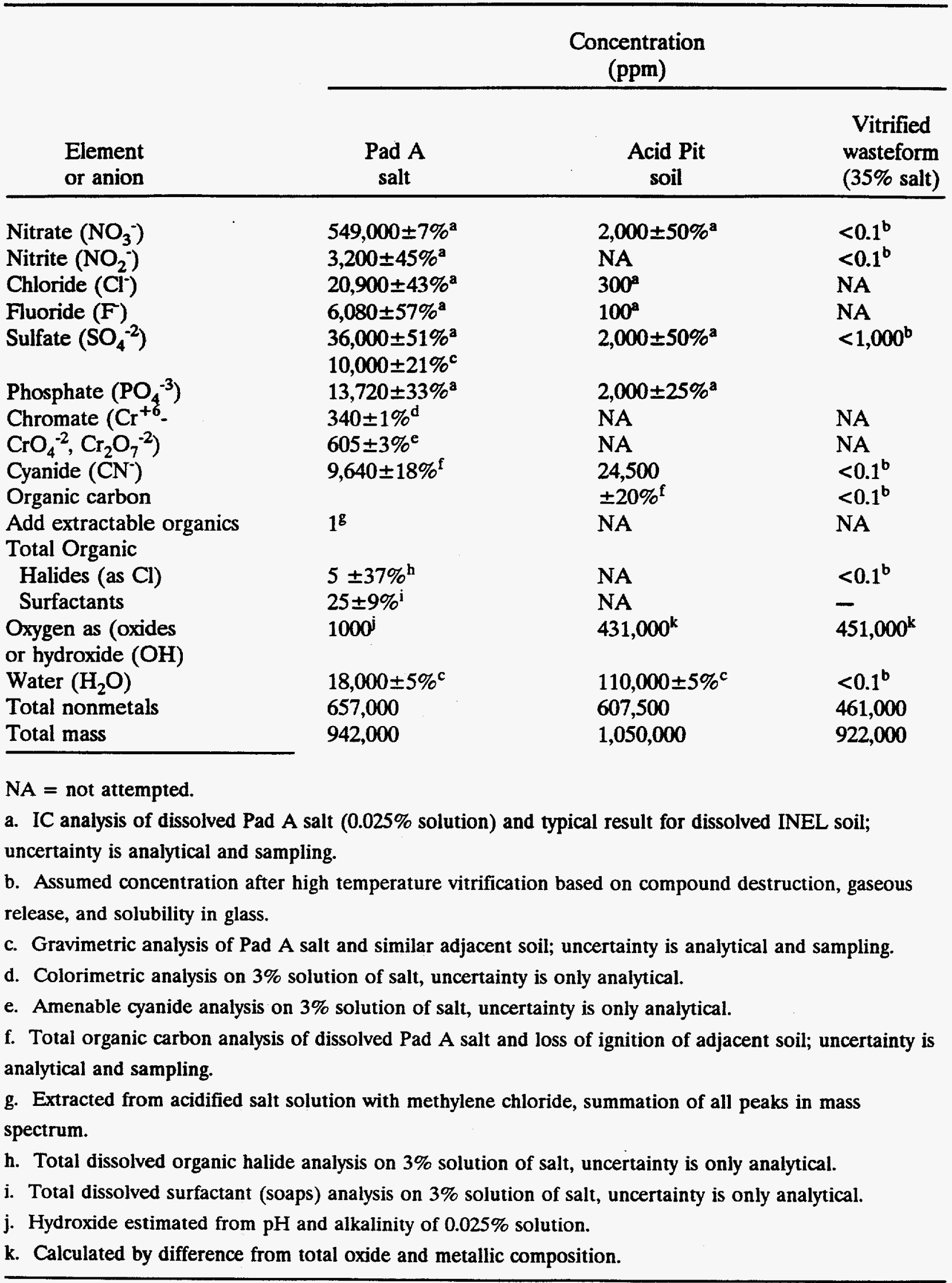


Table 7. Radionuclide content of Pad A salt, Acid Pit soil, and glass wasteforms.

\begin{tabular}{|c|c|c|c|c|}
\hline \multirow[b]{2}{*}{ Radionuclide } & \multicolumn{2}{|c|}{ Activity in $\mathrm{pCi} / \mathrm{g}$} & \multirow[b]{2}{*}{$\begin{array}{l}\text { Wasteform } \\
\text { (35\% salt) }\end{array}$} & \multirow[b]{2}{*}{$\begin{array}{l}\text { Wasteform } \\
\text { (theoretical) }\end{array}$} \\
\hline & $\begin{array}{c}\text { Pad A } \\
\text { salt }\end{array}$ & $\begin{array}{l}\text { Acid Pit } \\
\text { soil }\end{array}$ & & \\
\hline U-238, U-234 & $58 \pm 11 \%^{a}$ & $18 \pm 9 \% \mathrm{a}$ & $46 \pm 20 \%{ }^{b c}$ & 33 \\
\hline $\mathrm{U}-238, \mathrm{U}-234^{\mathrm{d}}$ & - & - & $75 \pm 33 \%^{c}$ & 88 \\
\hline $\mathrm{U}-235^{\mathrm{b}}$ & $1.5 \pm 12 \%$ & $2.6 \pm 17 \%$ & $1.9 \pm 12 \%$ & 2.1 \\
\hline Th & $0.7 \pm 6 \%$ & $1.3 \pm 12 \%^{e}$ & $1.1 \pm 21 \%{ }^{b c}$ & 1.1 \\
\hline $\mathrm{Pu}-238$ & $0.42 \pm 32 \% c$ & $<10^{\mathrm{b}}$ & $4 \pm 50 \% \%^{c}$ & $<8$ \\
\hline $\mathrm{Pu}-239$ & $0.27 \pm 19 \%{ }^{c}$ & $<100^{c}$ & $0.5 \pm 50 \% c$ & $<60$ \\
\hline Am-241 & $0.28 \pm 13 \%{ }^{\text {cd }}$ & $<0.2^{c}$ & $0.2 \pm 20 \% \mathrm{c}$ & $<0.23$ \\
\hline$A m-241^{d}$ & - & - & $72 \pm 4 \%$ d & 106 \\
\hline $\mathrm{Cs}-137^{\mathrm{b}}$ & $0.1 \pm 9 \%$ & $<0.1$ & $0.14 \pm 10 \%$ & $<0.1$ \\
\hline $\mathrm{K}-40^{\mathrm{b}}$ & $86 \pm 2 \%$ & $20 \pm 3 \%$ & & 44 \\
\hline
\end{tabular}

a. Gamma Spectrometry; nondestructive, average based on daughters Ra-226 and Th-234; uncertainty is analytical.

b. Gamma Spectrometry; nondestructive; uncertainty is analytical and sample inhomogeneity.

c. Alpha Spectrometry destructive; uncertainty is analytical and sample inhomogeneity.

d. Spike added as liquid to salt/soil mixture, wasteform as analyzed by Gamma Spectrometry; nondestructive uncertainty analytical and sample inhomogeneity.

e. Gamma Spectrometry; nondestructive, average based on daughters $\mathrm{Pb}-212, \mathrm{Tl}-208$, and $\mathrm{Ac}-228$; uncertainty is analytical.

Both qualitative and quantitative data were collected. The results are to provide information for waste nitrate salt and soil processing, volume and mass waste minimization and wasteform durability. Experimental and analytical data involved a variety of techniques and measurements. 
Compositional metal analysis for silicon, aluminum, iron, and calcium in the soils reveal the typical, somewhat siliceous, nature of the soil. Analysis of the salt for metals reveal they are exclusively (98\%) alkali (sodium, potassium, lithium) in nature. Upon heating the salt and soil, the goal is fixing sodium and potassium, which are very soluble and reactive metals that determine the leachability of the entire wasteform. The soil contains $23 \%$ less silicon by weight than pure sand. Aluminum and iron concentrations are sufficient for a durable final wasteform, but the soil was also deficient in calcium, compared to what is considered an optimum glass formulation.

Radionuclide content of the salts, soils, and glass wasteforms are summarized in Table 7. Both nondestructive large sample ( $>50 \mathrm{~g}$ ) gamma spectrometry and destructive small sample $(<5 \mathrm{~g}$ ) alpha spectrometry were used. Salts, soils, and glasses were radiologically analyzed at two laboratories. Nondestructive gamma counting performed on salts, soils, and glass samples is dependent on matching geometry (density, shape, particle size). Three spiked melts and a blank were leach-tested to determine the degree of fixation of radionuclides in the glass. The activity levels of these radioisotopes in the small salt and soil samples though above background would be below limits of detection even at a high-leach rate. Solutions containing Am-241, U-234, and Pu-242 were added in initial batch materials.

Alpha spectrometry was used for salt and wasteform concentrations of Pu-239, Pu-238, Am-241, U-234, and U-238. Gamma spectrometry was used for determining uranium, thorium, americium, and potassium in salts, soils, and wasteforms. Table 8 gives the estimated total alpha activity in the glass, based on the activity reported in Table 7. Am-241 and daughters of U-234 were detected in the glasses through gamma counting. Pu-242 is an alpha-emitters and would require alpha spectrometry for detection. These estimates are used to calculate the percentage leached from the glass reported in Table 8. As expected, based on the salt and soil data, $U$, Th, and $\mathbf{K}$ activity levels were measurable; $U$ and $T h$ were based on their daughter isotopes.

Leachate results help establish long-term durability, and processibility is determined from apparent viscosity and operational observations. Destruction of nitrous gases and metals volatilization was not determined because an actual joule melter with a cold-cap is required to simulate a production set up. Qualitative data was collected to describe the melt viscosity during pouring and the quality of the glass produced. These data and analysis methods are summarized in Appendix A of Reference 5 . 
Table 8. Metals and radionuclides leached from a 35\% Pad A salt glass wasteform during the TCLP test.

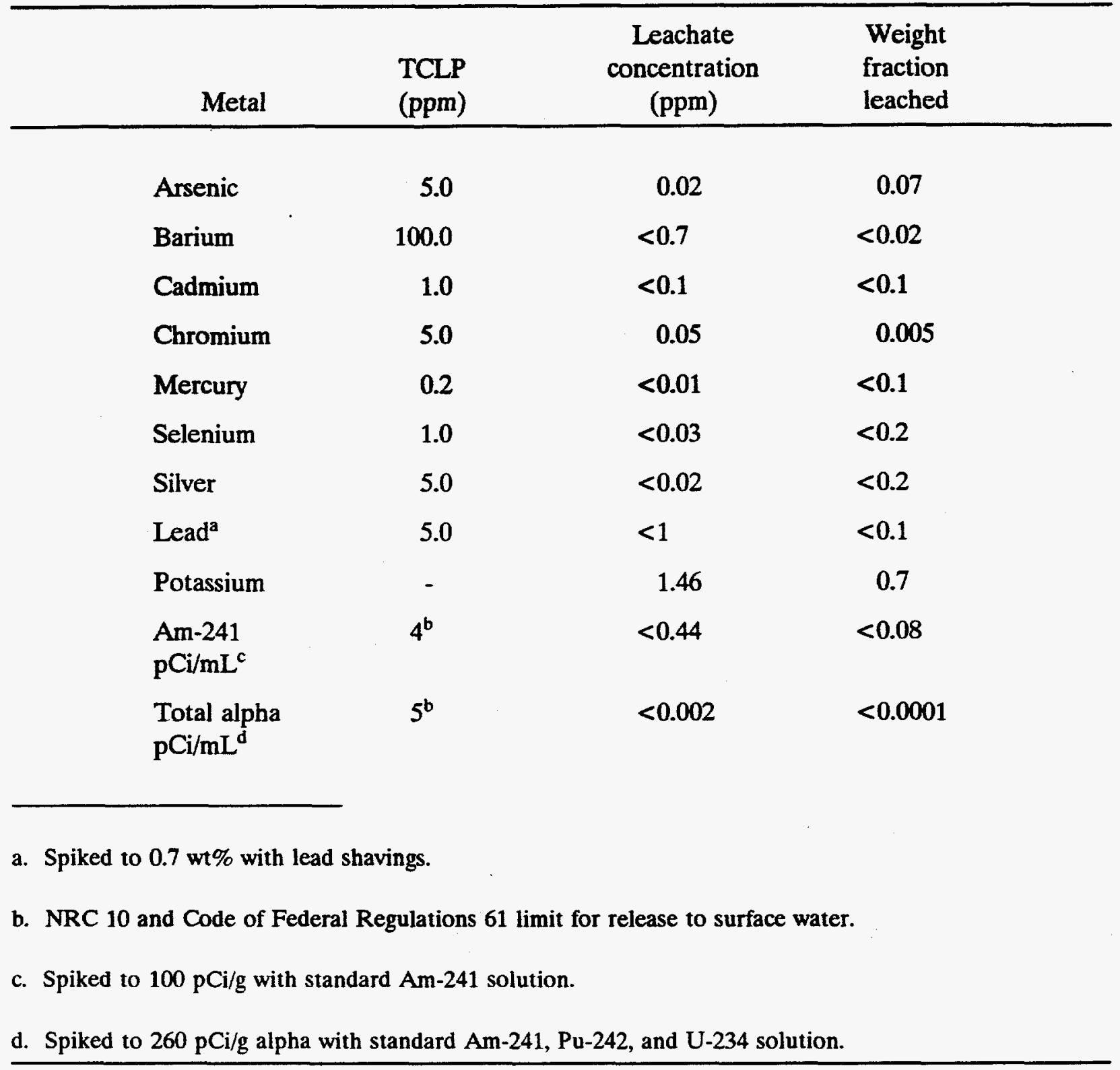




\section{RESULTS AND DISCUSSION}

The results of three aspects of high temperature salt/soil co-processing simulating joule-heated vitrification technology are discussed below: (a) waste processibility, (b) wasteform durability, and (c) waste minimization. Both quantitative and qualitative data were used to verify that this process could produce a glass that was workable, durable, and gave some volume reduction.

\subsection{Processibility}

The color of the glass produced from this waste was black-green to very dark black, somewhat like IEB. Glass color depends on how reduced the melt was. All melts were reduced to facilitate waste reactions and convert as much of the $\mathrm{NO}_{x}$ to $\mathrm{N}_{2}$ as possible. The type and amount of carbon added to the batch were the primary refractors in its reductive character. Differences were noted between flour, activated charcoal, and lamp black as carbon sources. Less reduced glasses were green, more reduced were black. Soil mineral matter was incorporated in the melt with metal phases. Some slag (metallic iron) was apparent in reduced melts. Devitrification (crystallization) in some melts with $\mathrm{ZnO}_{2}$ and $\mathrm{TiO}_{2}$ was noted.

Various fluxing agents were used to achieve appropriate melt viscosities. Small quantities of these fluxing agents can result in significant changes in melt viscosity, influence glass oxidation-reduction, and enhance handling properties. Boric acid (0 to 8\%), fluorspar ( 0 to $2 \%)$, and carbon (5 to $7 \%$ ) additives were the most influential. Adding carbon reduced the nitrate, thus decreasing nitrous gas emissions. Carbon and boron seemed to decrease foaming and crucible attack. Viscosities were influenced most by total alkali and boron content. Borosilicate glasses gave workable viscosities with low salt $(<20 \%)$ loadings. Boric acid was also observed to reduce crucible corrosion.

The viscosity of the melt during pouring is the primary processing information collected during this testing. Though we were unable to measure viscosity directly, it was estimated visually and quantitatively by melts with greater than $65 \mathrm{wt} \%$ of the final mass poured. Table 9 gives estimated viscosities of poured melts. The estimated viscosity compares favorably to this weight percentage of the total glass that freely poured from the crucible.

Twenty melts had acceptable processing viscosity. Only two had estimated viscosities around 1,000 P, most were around 700. The viscosity of the melted salt/soil increased with decreasing salt content and increasing soil content. Melt formulations with salt contents below $17 \%$ were not pourable ( $>1,000 \mathrm{P}$ ). Salt contents of 17 to $22 \%$ were at the limit of processing with viscosities near $1,000 \mathrm{P}$.

Lower silicon and higher sodium concentrations generally decrease viscosity and durability. Normally the more durable glasses had lower sodium concentrations and were difficult to pour. The very high alkali (39 to $50 \%$ salt) and high ( 27 to $38 \%$ salt) alkali glasses had some of the lowest viscosities and were easily processed. 
Table 9. Waste minimization and processability of INEL Pad A nitrate salt and Acid Pit soil at $1500^{\circ} \mathrm{C}-1575^{\circ} \mathrm{C}$.

\begin{tabular}{|c|c|c|c|c|c|}
\hline & $\begin{array}{c}\text { IEB-low } \\
\text { alkali } \\
\text { (<20\% salt) }\end{array}$ & $\begin{array}{l}\text { Recommended } \\
\text { composition } \\
\text { (21-25\% salt) }\end{array}$ & $\begin{array}{l}\text { Borosilicate } \\
\text { glass }^{a}\end{array}$ & $\begin{array}{c}\text { Medium } \\
\text { alkali } \\
\text { (30\% salt) }\end{array}$ & $\begin{array}{l}\text { High } \\
\text { alkali } \\
\text { (35-50 } \\
\% \text { salt) }\end{array}$ \\
\hline Salt/soil ratio & 0.26 & 0.43 & 0.47 & 0.59 & $0.78-1.5$ \\
\hline Alkali as $\mathrm{Na}_{2} \mathrm{O}$ percent & 12 & $14-19$ & $14-15$ & 22 & $27-39$ \\
\hline $\begin{array}{l}\text { Experiment }{ }^{\mathrm{b}} \text { estimated } \\
\text { viscosity poise }\end{array}$ & NP & $800-1,200$ & $400-700$ & $400-700$ & $250-400$ \\
\hline $\begin{array}{l}\text { Theoretical } \\
\text { viscosity poise }\end{array}$ & 2,000 & 320 & 250 & 100 & 10 \\
\hline $\begin{array}{l}\text { Amount }{ }^{d} \text { poured } \\
\text { percent }\end{array}$ & NP & 60 & 80 & 80 & 90 \\
\hline $\begin{array}{l}\text { Metals }{ }^{\mathrm{e}} \text { volatilized } \\
\text { percent }\end{array}$ & NP & 1.7 & $<1$ & 2.1 & 8.4 \\
\hline Mass reduction percent & $15^{\mathrm{f}}$ & 24 & None & 30 & 38 \\
\hline $\begin{array}{l}\text { Volume reduction } \\
\text { percent }\end{array}$ & $40^{f}$ & 61 & 43 & 67 & 73 \\
\hline Density $(g / c c)$ & NP & 2.3 & 2.4 & 2.3 & 2.3 \\
\hline \multicolumn{6}{|c|}{ NP $=$ Not Pourable (too viscous) } \\
\hline \multicolumn{6}{|l|}{ IEB = Iron Enriched Basalt. } \\
\hline \multicolumn{6}{|c|}{ a. Includes boron and calcium additives. } \\
\hline \multicolumn{6}{|c|}{ b. Estimated by eye while pouring. } \\
\hline \multicolumn{6}{|c|}{ c. From Geochemical Program Package a semi empirical viscosity temperature model. } \\
\hline \multicolumn{6}{|c|}{$\begin{array}{l}\text { d. Difference between calculated final mass (allowing for } \mathrm{NO}_{x} \text {, water and } \mathrm{CO}_{3} \text { loss) and actual measured } \\
\text { value. }\end{array}$} \\
\hline \multicolumn{6}{|c|}{ e. Approximate average values, highly variable depending on time spent in pour. } \\
\hline
\end{tabular}


The very-high alkali and high-alkali glasses generally had the lowest viscosities, with 67 to $97 \%$ poured. Experiments with salt/soil ratios of 0.43 generally had the highest viscosities with 53 to $66 \%$ of the glass poured. The borosilicate glasses showed uniformly low viscosities with 81 to $83 \%$ poured. The durable glasses with additives had slightly higher viscosities with 72 to $80 \%$ poured depending on the quantity and type of additives. The viscosities of the two high-alkali earth melts, were also low, with $74 \%$ and $81 \%$ poured.

Processible glass viscosity of salt/soil mixtures requires temperatures above $1500^{\circ} \mathrm{C}$ and alkali contents above $11 \%$. High viscosity, preventing glass pouring, occurred where salt content was below $17 \%$ or batch material (probably alkali) was lost due to overflow during the melt. Batches with similar starting recipes, but without overflow, were pourable. Temperature effects on melt viscosity could not be quantitatively determined. Variations in the handling and timing of the melt while removing it from the furnace and pouring, were more of a factor in observed viscosity differences than furnace temperature.

Corrosivity of the melt is an important factor in processing. Corrosivity on the refractory was determined qualitatively by describing attack on the crucible. Corrosivity on electrode material was measured quantitatively by weight loss on sample electrode coupons. A summary of crucible attack and electrode corrosion results is provided in the Appendix A of Reference 5.

Figure 9 shows chromium and the molybdenum coupons imbedded in the glass melt. The molybdenum coupon exhibited a slight increase while the chromium coupon exhibited a weight loss. Neither exhibited significant visual signs of corrosion. Weight increase is attributed primarily to adhering glass residue. The graphite coupon was completely oxidized either from contact with the air or nitrate salts. Graphite is an unsuitable electrode material for waste formulations or processing conditions involving significant exposure to oxygen.

Crucible attack seemed to decrease with addition of carbon, calcium, and boron. Corrosion does not seem to correlate to the carbon-to-salt ratio. Metal and slag formation was controllable through adjustments in the carbon-to-salt ratio. Lamp black was found to be more reducing than activated carbon, resulting in the formation of a separate metal phase in each of these melts.

\subsection{Waste Minimization}

Waste minimization is reducing the volume of the waste in the final wasteform by eliminating void volume (increasing bulk density) and generating little if any secondary waste (such as volatile metals) to be treated in the process. Mass is eliminated through (a) organic combustion, (b) reduction of nitrate to nitrogen gas, and (c) eliminating water. In this laboratory scale vitrification, melting reduced the volume of the wastes by eliminating void volume and removing nitrates, water, and carbon.

Final vitrified densities averaged $2.30 \pm 0.5$ compared to bulk density (specific gravity) of the soil (1.57), and salt (0.77). The volume and mass reductions for each melt were measured using masses and bulk densities of both input salts and soils and the final glass wasteform. Other properties measured that had bearing on volume reduction were moisture content, total organic carbon, and loss on ignition. 

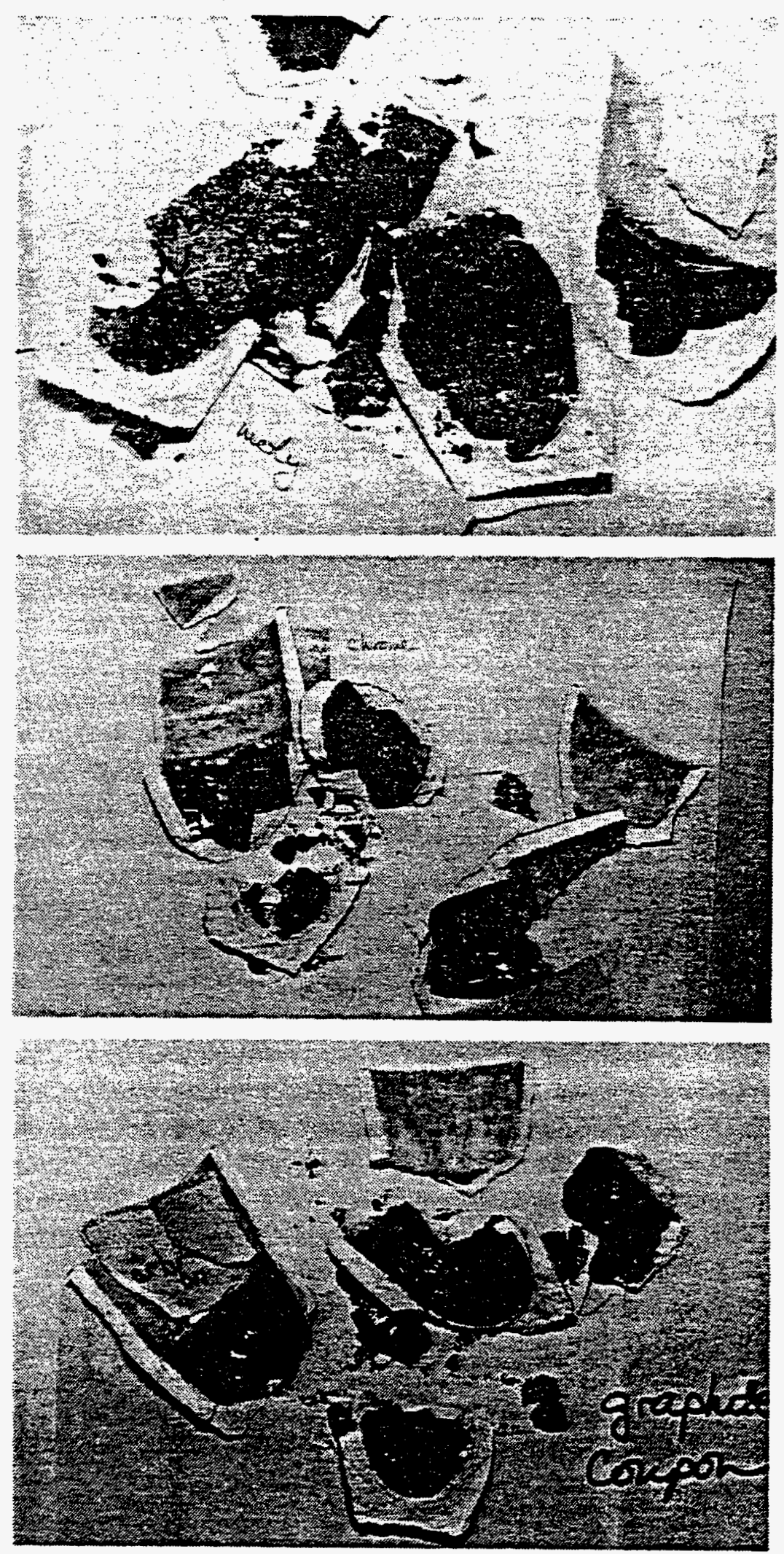

Figure 9. Electrode coupons in glass melts.

\section{Molybdenum coupon embedded in glass melt}

\author{
Chromium coupon \\ embedded in glass melt
}

Graphite coupon

disappeared in glass melt 
High amounts of salts, 35 to $50 \%$, gave the greatest volume and mass reduction. These high alkali glasses resulted in mass reductions of 25 to $41 \%$ and 68 to $77 \%$ in volume. A more durable glass with less alkali but no additives had a salt/soil ratio of 0.43 , reduced mass 22 to $27 \%$, and volume 61 to $68 \%$. Borosilicate glasses actually showed slight mass increases with volume reductions 32 to $56 \%$. Durable glasses with other additives (limestone, sand) showed lower mass reductions up to $19 \%$ and reduced total volume 51 to $64 \%$, depending on the quantity and type of additives used to increase durability. The table in Appendix A of Reference 5 gives the calculated mass reduction for each of the melts.

Volume reduction comes from mass loss and void space elimination. Mass reduction can come from $\mathrm{CO}_{2}, \mathrm{H}_{2} \mathrm{O}, \mathrm{SO}_{x}, \mathrm{NO}_{x}, \mathrm{~N}_{2}$, gas loss and metals volatilization. When the final mass producing the primary gases $\mathrm{CO}_{2}, \mathrm{H}_{2} \mathrm{O}$, and $\mathrm{NO}_{\mathrm{x}}$ is compared to the measured final glass mass (calculated and experimentally determined in Appendix A of Reference 5) metals volatilization can be estimated. Table 9 lists estimates of both aspects of mass loss for various classes of melts. Increased evaporation of material from the melt correlates with overall higher alkali contents. Borosilicate glasses appear to have no metals volatilization. It is possible that the added material to enhance durability compensated for the mass lost from metals volatilization, or actually decreased it.

Metal volatilization is unavoidable in any ceramic or glass production and comprises a large part of the secondary wastes for any high-temperature process. Joule melters can minimize these with a cold-cap maintained in the melter. Higher temperature melters using other heating sources such as plasma arc can result in greater volatility because of the higher temperature, turbulence of the process and lack of a protective cap. A high temperature joule melter should have distinct advantages in eliminating emission at the source through use of the cold-cap, quiescent process, and melt chemistry control.

Overall volume and mass reduction includes the volume and mass of secondary wastes. Recycling these secondary wastes is possible to some extent in any melter. Extent of recycling is dependent on the ability of the melter to incorporate species, which have previously offgassed or are used to scrub the gases (alkaline solutions), into the wasteform. Volume reductions, even for highly durable glass formulations, are greater than $50 \%$ when another wastestream is used for the matrix.

Wastes can be used for the binder, the basic material of glass (silicon), and flux; they improve handling and durability of glass. INEL contaminated soil was used as a binder in this study as a calcium and silicon source in place of sand and limestone. Wastes could be used for needed flux ingredients, such as discarded contaminated racshing rings (used for neutron absorption) for boron. Use of waste as the binder and flux can give overall mass reduction up to $40 \%$ and a volume reduction of $75 \%$ in this vitrification process.

\subsection{Durability}

Durability of a wasteform can be determined in several ways by measuring different parameters. Physical hardness or strength is determined by compressive strength. Resistance to weathering and water intrusion is determined by porosity, density, or freeze thaw cycling. Leaching, the most widely used parameter, is determined by measuring structural metals or specific waste components in leachate solutions after some period of time. Durability in these tests was quantitated by resistance 
to leaching of specific toxic metals in the EPA TCLP and resistance to structural metal loss over time in the NRC PCT.

Four glasses were tested for leachability with the EPA TCLP test. Leach tests were performed on two glasses with $35 \%$ Pad A salts (22\% alkali), one with $25 \%$ Pad A salts (16\% alkali), and one a blank batch made from simulated salt and soil with no actual waste and not spiked either radiologically or with toxic metals. The TCLP leachates were analyzed for the required eight EPA toxic metals, potassium, nitrate, and gross alpha and gamma emitting isotopes and their daughters. Results are presented in. Tables 8 and 10.

TCLP leachates were prepared from $100 \mathrm{~g}$ of glass and $2 \mathrm{~L}$ of leaching solution according to EPA Method 1311. The leachate toxic metal contents, measured by INAA or atomic absorption spectrophotometry (AAS), were generally below detection limits and are provided in terms of lower limit of detection (LLD). Trace arsenic and chromium metal were detected, but all TCLP metals were at least $50 \%$ below limits. No nitrate was detected in the leachates demonstrating destruction by the vitrification process. Potassium (a matrix metal) was present in the leachates. Concentrations in leachate were proportional to alkali concentration in the glass (22 wt\% in glass-1.46 ppm in leachate, $16 \mathrm{wt} \%$ in glass-1.05 ppm in leachate).

The PCT test is similar to the Materials Characterization MCC-3 test and is a comparative test used for high-level waste glass studies. The test does not simulate long-term performance as much as provide a standard method to compare vitrification wasteforms, glasses, and ceramics. The test is longer than the TCLP, ( 7 days versus 1 day), run at elevated temperature $\left(90^{\circ} \mathrm{C}\right.$ versus $25^{\circ} \mathrm{C}$ ), uses a slightly different particle size, and tests for the breakdown of the glass structure rather than specific encapsulated elements.

Six melts with alkali (sodium and potassium) oxide contents ranging from 15 to $39 \%$ were given the high-level wasteform PCT. The results are summarized in Table 10. Leachate was measured for material loss (aluminum, boron, barium, calcium, cadmium, titanium, nickel, chromium, iron, potassium, magnesium, manganese, sodium, phosphorous, silicon, and titanium) by ICP-AES. The results of elemental leaching are summarized in Table 10. Most are leached in proportion to the alkali content in the wasteform.

Metal leaching was significant in high alkali wasteforms, but low in so called durable wasteforms. Only the most durable wasteform tested with $23 \%$ salt and $49 \%$ soil (15\% alkali oxide, $6 \%$ boron oxide, $7 \%$ calcium oxide, $9 \%$ aluminum oxide, and $59 \%$ silicon oxide) passed the PCT. This means they would be suitable as a high-level waste glass though there is not a specific leach limit in this test as there is in the TCLP.

High silicon content gave the most durable waste product. INEL Acid Pit soil contains 23\% less silicon by weight than sand. Up to $13 \%$ sand was added in some melts to raise the silica content closer to that of a typical soda lime glass, 65 to $70 \%$ silicon dioxide. The highly durable glass that had a silicon dioxide content of $64 \mathrm{wt} \%$ was suitable for containing high level waste according to leachate analysis in the PCT test. Glasses with 59\% silicon dioxide passed TCLP. Glasses with alkali contents above $26 \%$ and silicon dioxide below $55 \%$ gave an observable increase in silicon leaching but would still pass TCLP and may be acceptable for LLW. 
Table 10. Metal leaching from glass wasteforms during PCT test.

\begin{tabular}{|c|c|c|c|c|c|c|}
\hline \multirow{2}{*}{$\begin{array}{c}\text { \% Pad A } \\
\text { Salt } \\
\text { Metal }\end{array}$} & \multicolumn{2}{|c|}{41} & \multicolumn{2}{|c|}{28} & \multicolumn{2}{|c|}{23} \\
\hline & $\begin{array}{l}\text { Leachate } \\
\text { Conc. } \\
\text { (ppm) }\end{array}$ & $\begin{array}{l}\text { Weight } \\
\text { Fraction } \\
\text { Leached }\end{array}$ & $\begin{array}{c}\text { Leachate } \\
\text { Conc. } \\
\text { (ppm) }\end{array}$ & $\begin{array}{l}\text { Weight } \\
\text { Fraction } \\
\text { Leached }\end{array}$ & $\begin{array}{l}\text { Leachate } \\
\text { Conc. } \\
\text { (ppm) }\end{array}$ & $\begin{array}{l}\text { Weight } \\
\text { Fraction } \\
\text { Leached }\end{array}$ \\
\hline Aluminum & 33.7 & 0.013 & 9.7 & 0.0035 & 2.8 & 0.0013 \\
\hline Boron & 0.1 & 0.0019 & $<0.1$ & $<0.003$ & 2.4 & 0.0028 \\
\hline Barium & $<0.01$ & $<0.0004$ & 0.014 & 0.00035 & $<0.01$ & $<0.0003$ \\
\hline Calcium & 2.1 & 0.0047 & 0.8 & 0.0015 & 3.0 & 0.0015 \\
\hline Chromium & 0.5 & 0.059 & $<0.1$ & $<0.01$ & $<0.1$ & $<0.01$ \\
\hline Iron & 1.1 & 0.0018 & 0.88 & 0.00094 & $<1$ & $<0.001$ \\
\hline Potassium & 125 & 0.042 & 14 & 0.0048 & 6 & 0.0025 \\
\hline Magnesium & $<0.5$ & $<0.004$ & 0.3 & 0.0011 & $<0.5$ & $<0.005$ \\
\hline Manganese & $<0.02$ & $<0.001$ & 0.02 & 0.00067 & $<0.02$ & $<0.001$ \\
\hline Sodium & 585 & 0.095 & 59 & 0.0135 & 16 & 0.0050 \\
\hline Silicon & 187 & 0.014 & 53 & 0.0039 & 29 & 0.0022 \\
\hline Titanium & $<0.1$ & $<0.001$ & 0.13 & 0.00083 & $<0.1$ & $<0.001$ \\
\hline
\end{tabular}

Leach testing verified that metal oxides such as calcium, aluminum and boron could produce durable glasses with a lower silicon content than normal glass. This was tested with the intent of maximizing the salt content in the glass while minimizing nonwaste additives. Up to $10 \%$ limestone was added to increase calcium content. This increased the final calcium concentration in the glass from 2 to $3 \%$ to 7 to $8 \%$, which approaches a more typical and durable glass formulation.

The three INEL salt and soil melts submitted to the TCLP were spiked with lead, uranium, plutonium, and americium. Proportional counting (gross alpha) and gamma spectrometry were used to analyze these leachates for radionuclides. Destructive alpha spectrometry and nondestructive gamma spectrometry was used on the glass wasteforms and salts. Only gamma spectrometry was used for radionuclide analysis of soils used in this test. Spiked batches had $2 \mathrm{~mL}$ of spike solution added to initial batch materials giving theoretical radionuclide concentration after melting of $55 \mathrm{pCi} / \mathrm{g} \mathrm{U}$, $100 \mathrm{pCi} / \mathrm{g} \mathrm{Am}, 100 \mathrm{pCi} / \mathrm{g} \mathrm{Pu}$.

Radionuclide concentrations from TCLP leachates are listed in Table 8. Total alpha concentrations in these leachates were not statistically different than the unspiked blank made with surrogate salts and soils. The leaching of $\mathrm{Pu}, \mathrm{Am}$ and $\mathrm{U}$ from these glasses, appears, from these 
limited leachate results to be less than other heavy metals. The leach index (fraction in leachate compared to that in glass) for TRU was at least 20 times lower than that of tightly bound chromium. No gamma emitters were detected in the leachates including the spiked Am-241. 


\section{QUALITY ASSURANCE/CONTROL}

\subsection{QA Laboratory Audits and Surveillance}

All laboratories used in this characterization and testing are under a regular quality program. NRT General Atomics Program Plan conducted audits during the laboratory testing and audits the analytical laboratory. A Quality Assurance Program Document (QAPD) was prepared to define the quality assurance (QA) elements that were applicable to the NRT portion of the project (forming glass wasteforms and TCLP testing). The QA plan for the NRT testing is described in QAPD-9040-3951, Quality Assurance Program Document, within Appendix A of Reference 5. QA Surveillance was conducted during the laboratory testing by QA personnel to ensure that QAPD requirements specified for this project were satisfied. This NRT QA Plan is detailed in the Appendix A of Reference 5. TCT is under the EG\&G Idaho Environmental Restoration Department (ERD) quality plan for performing organization involved in environmental related activities. PNL operates under their sites's laboratory quality program as do RML and ECL under the INEL. Quality control (QC) procedures were applied to both the experimental testing and salt, soil, and wasteform characterization.

\subsubsection{Experimental Procedure}

Quality control was exercised in sample handling, sample melting, and wasteform testing. The waste to be processed was homogenized extensively. The melt temperature was controlled within $1 \%$. The entire procedure was reproducible as evidenced by the similarity of viscosities and final densities of replicate batches [5\% relative percent difference (RPD) in densities for similar melts]. Experimental variations were most pronounced in glass pouring. The time to remove the crucible from the furnace and pour the waste determined viscosity to be more than the final furnace temperature. Density differences in glasses may also be related more to the casting rather than formulation, though this is hard to verify.

The testing procedure was reproducable as shown in Table 11 . Nearly identical initial batch formulas, were selected for analysis to see how well the overall vitrification testing can be reproduced. Two glass samples, from a single melt, and their TCLP leachates were also analyzed to demonstrate the repeatability of the leaching method. Samples of a blank melt (made from simulated salt and soil) and the blank extract, the original leaching solution, were also analyzed along with the test samples (glass) to provide relative references or basis for comparison.

Good reproducibility in testing is shown in the set of similar experiments that all had a salt/soil ratio of 0.43 with no matrix additives; mass reduction ranged from 22 to $27 \%$ and volume reduction ranged from 61 to $68 \%$. The two glasses with identical feed composition gave similar leachate analytical results. Two leachates were made from a split of one glass sample and their test results were also expected to be similar. The reason for testing glasses or leachates with the same feed or glass composition was to see how well the test procedures can be reproduced. A blank made with synthetic salt and soil was used for comparison to the spiked/rad samples. This was required to properly interpret radionuclides results as of TCLP leachates. The batch formulas for the melts are 
Table 11. Laboratory reproducibility and similarity of hot and simulate duplicate melts.

\begin{tabular}{|c|c|c|c|c|}
\hline Type of glass & Parameter & $\mathrm{Hot}^{\mathrm{a}}$ & Simulate $^{b}$ & $\begin{array}{c}\text { Difference } \\
\text { percent }\end{array}$ \\
\hline \multirow{4}{*}{$\begin{array}{l}\text { Borosilicate glass } \\
23 \% \text { salt }\end{array}$} & Density & 1.56 & 2.32 & $39^{c}$ \\
\hline & Percent poured & 80 & 81 & 1 \\
\hline & Mass reduction & $\begin{array}{c}\text { none } \\
(-1)\end{array}$ & $\begin{array}{l}\text { none } \\
(-7)\end{array}$ & 6 \\
\hline & Volume reduction & 28 & 48 & 20 \\
\hline \multirow{4}{*}{$\begin{array}{l}\text { Sodium glass } \\
25 \% \text { salt }\end{array}$} & Density & 2.34 & 2.11 & $10^{c}$ \\
\hline & Percent poured & 73 & 76 & 3 \\
\hline & Mass reduction & 8 & 4 & 4 \\
\hline & Volume reduction & 56 & 49 & 7 \\
\hline \multirow{4}{*}{$\begin{array}{l}\text { Borosilicate glass } \\
28 \% \text { salt }\end{array}$} & Density & 1.82 & 2.28 & $22^{c}$ \\
\hline & Percent poured & 60 & 55 & 5 \\
\hline & Mass reduction & 42 & 47 & 5 \\
\hline & Volume reduction & 65 & 74 & 9 \\
\hline \multicolumn{5}{|c|}{. Pad A salt and acid pit soil. } \\
\hline \multicolumn{5}{|c|}{ b. Surrogate salt and noncontaminated acid pit soil. } \\
\hline
\end{tabular}

provided in Table 6-3 and 6-4 in Appendix A of Reference 5. Two batch formulas of 35\% salt and one with $25 \%$ salt split into two glass samples gave similar differences in expected and final. The measured $\mathrm{Na}, \mathrm{K}$, and $\mathrm{Cr}$ contents of the glasses were compared to the predicted contents.

\subsubsection{Laboratory Data}

The actual analytical methods that were followed in laboratory activities for this project are referenced in Appendix A of Reference 5. EPA QC data parameters such as precision, accuracy, completeness and representativeness are discussed below for: (a) the salt and soil characterization (Tables 12 and 13), (b) final wasteform testing characterization (Tables 14 through 16), and (c) melting/experimental procedure (Tables 11 and 17). Analytical results were verified through use of different analytical techniques, spikes, duplicates (measurements on the same sample, different portions of a composited sample, and different analytical techniques on the same sample), National Institute of Standards and Technology (NIST) standards, interlaboratory comparisons, and mass balance. The soil was visually homogeneous, whereas the salt contained generally yellow flaky 
Table 12. Comparison of Pad A salt and acid pit soil results by destructive and nondestructive analysis.

\begin{tabular}{|c|c|c|c|c|c|c|}
\hline Metal & Waste & $\mathrm{ICP}^{\mathrm{a}}$ & INAA $^{b}$ & $\mathrm{AA}^{c}$ & $\begin{array}{l}\text { Gamma } \\
\text { Spec. }^{d}\end{array}$ & $\mathrm{RPD}^{\mathrm{e}}$ \\
\hline & & \multicolumn{4}{|c|}{ Concentration in ppm } & Percent \\
\hline $\mathbf{N a}$ & $\operatorname{Pad} A$ salt ${ }^{f}$ & $240,000 \pm 5 \%$ & $200,000 \pm 0.5 \%$ & $189,100 \pm 5 \%$ & & 17 \\
\hline $\mathbf{K}$ & $\operatorname{Pad} A$ salt $^{\mathrm{f}}$ & $85,800 \pm 26 \%$ & $75,600 \pm 24 \%$ & $81,600 \pm 25 \%$ & $89,000 \pm 2 \%$ & 12 \\
\hline $\mathrm{Cr}$ & Pad A salt ${ }^{f}$ & $404 \pm 5 \%$ & $390 \pm 33 \%$ & & & 3 \\
\hline $\mathrm{Na}$ & Acid pit soils & $13,800 \pm 25 \%$ & $10,300 \pm 0.5 \%$ & & & 25 \\
\hline $\mathbf{K}$ & Acid pit soilg & $21,000 \pm 25 \%$ & $20,400 \pm 14 \%$ & & $24,000 \pm 3 \%$ & 3 \\
\hline $\mathrm{Cr}$ & Acid pit soilg & $62 \pm 25 \%$ & $63 \pm 33 \%$ & & & 2 \\
\hline
\end{tabular}

a. ICPlasma analysis performed by TCT, Environmental Chemistry (EC) INEL and PNL, uncertainty includes analytical and sample variability.

b. NAA performed on salt and soil used in test by NRT, uncertainty is analytical, Cr values have uncertainty from substantial $\mathrm{Na}$ interference.

c. AA analysis performed on salt used in test by NRT, uncertainty is estimated analytical only.

d. Gamma Spectrometry of K-40 in salt used in melts. Analysis by NRT and RML INEL, total potassium based on $0.0119 \%$ isotopic composition, uncertainty is counting only.

e. RPD between ICP and INAA results.

f. Pad A salt data based on analyses of composited samples from one drum.

g. Acid Pit data based on analysis of various sections of core samples. 
Table 13. Comparison of Pad A salt TCLP metals results by destructive and nondestructive analysis.

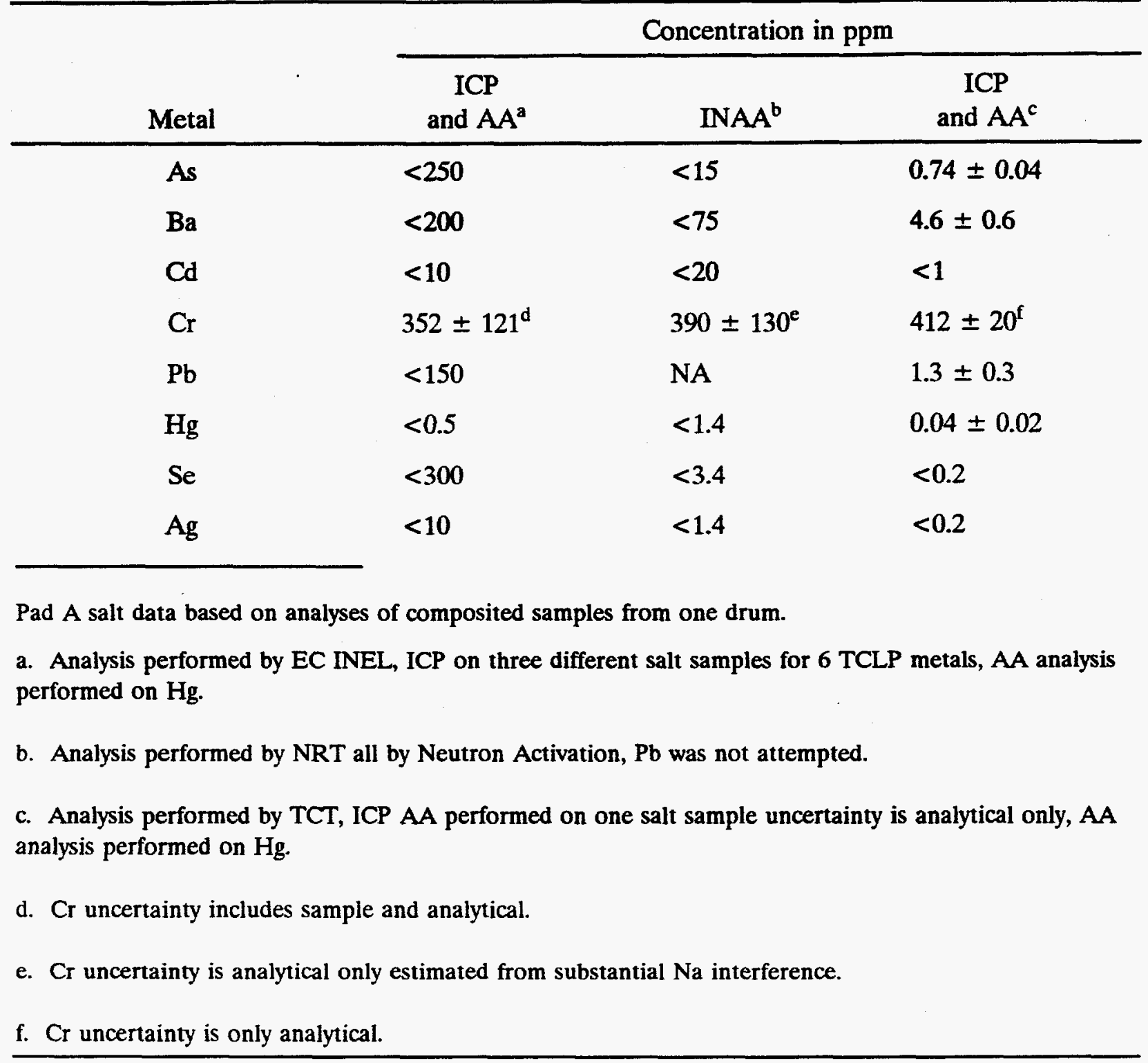


Table 14. Comparion of NIST standard glass values with measured results by destructive ICP analysis.

\begin{tabular}{|c|c|c|c|}
\hline $\begin{array}{l}\text { Element } \\
\text { oxide }\end{array}$ & $\begin{array}{l}\text { NIST glass } \\
\text { SRM623 }\end{array}$ & $\begin{array}{c}\text { Measured } \\
\text { concentration }\end{array}$ & $\mathrm{RPD}^{\mathrm{b}}$ \\
\hline & \multicolumn{3}{|c|}{ Percent } \\
\hline $\mathrm{Al}_{2} \mathrm{O}_{3}$ & 6.30 & $6.08 \pm 0.09$ & 3.5 \\
\hline $\mathrm{CaO}$ & 0.70 & $0.75 \pm 0.17$ & 7.1 \\
\hline $\mathrm{Na}_{2} \mathrm{O}$ & 6.40 & $6.9 \pm 0.22$ & 8.3 \\
\hline $\mathrm{SiO}_{2}$ & 73.00 & $67.65 \pm 0.59$ & 7.3 \\
\hline $\mathrm{K}_{2} \mathrm{O}$ & 0.6 & $<0.5$ & \\
\hline $\mathrm{B}_{2} \mathrm{O}_{3}$ & 10.7 & $9.99 \pm 0.12$ & 6.6 \\
\hline $\mathrm{BaO}$ & 2.20 & $2.04 \pm 0.03$ & 7.3 \\
\hline TOTAL & 99.9 & $93.46 \pm 0.60$ & 6.4 \\
\hline \multicolumn{4}{|c|}{$\begin{array}{l}\text { a. Measured metal contents in glasses using ICP at PNL, uncertainty is standard deviation of } 4 \\
\text { rrials. }\end{array}$} \\
\hline \multicolumn{4}{|c|}{$\begin{array}{l}\text { b. RPD }=\text { difference between standard and measured content in glass }=1 \text {-measured content in } \\
\text { glass/standard content in glass. }\end{array}$} \\
\hline
\end{tabular}


Table 15. Expected vs. measured metals content of glass by destructive ICP analysis.

\begin{tabular}{|c|c|c|c|c|}
\hline $\begin{array}{c}\text { Pad A salt in } \\
\text { batch } \\
\text { Wt } \%\end{array}$ & Element & $\begin{array}{c}\text { Expected } \\
\text { concentration } \\
(\mathrm{ppm})^{\mathbf{a}}\end{array}$ & $\begin{array}{c}\text { Measured } \\
\text { concentration } \\
(\mathrm{ppm})\end{array}$ & $\begin{array}{c}\text { RPD-mass } \\
\text { difference } \\
(\%)\end{array}$ \\
\hline \multirow[t]{6}{*}{$23 \%$ salt } & A $\mathbf{I}$ & 7.21 & 8.00 & 11 \\
\hline & $\mathrm{Ca}$ & 5.67 & 5.47 & 4 \\
\hline & $\mathrm{Fe}$ & 1.43 & 2.11 & 32 \\
\hline & $\mathbf{K}$ & 4.45 & 5.73 & 29 \\
\hline & $\mathrm{Na}$ & 11.46 & 8.57 & 25 \\
\hline & $\mathbf{S i}$ & 58.96 & 57.23 & 3 \\
\hline \multirow[t]{6}{*}{$28 \%$ salt } & Al & 8.99 & 10.94 & 22 \\
\hline & $\mathrm{Ca}$ & 1.83 & 1.50 & 18 \\
\hline & $\mathrm{Fe}$ & 1.87 & 2.37 & 27 \\
\hline & $\mathbf{K}$ & 6.47 & 6.99 & 8 \\
\hline & $\mathrm{Na}$ & 14.23 & 11.75 & 17 \\
\hline & $\mathrm{Si}$ & 63.33 & 58.44 & 8 \\
\hline \multirow[t]{6}{*}{$41 \%$ salt } & Al & 7.87 & 9.78 & 24 \\
\hline & $\mathrm{Ca}$ & 1.52 & 1.27 & 16 \\
\hline & $\mathrm{Fe}$ & 1.66 & 1.56 & 6 \\
\hline & $\mathbf{K}$ & 8.50 & 7.11 & 16 \\
\hline & $\mathrm{Na}$ & 21.33 & 16.62 & 22 \\
\hline & $\mathrm{Si}$ & 55.42 & 56.55 & 2 \\
\hline \multirow[t]{6}{*}{$46 \%$ salt } & $\mathrm{Al}$ & 7.31 & 8.80 & 20 \\
\hline & $\mathrm{Ca}$ & 1.40 & 1.20 & 14 \\
\hline & $\mathrm{Fe}$ & 1.55 & 2.23 & 44 \\
\hline & $\mathbf{K}$ & 9.53 & 10.62 & 11 \\
\hline & $\mathrm{Na}$ & 24.90 & 18.09 & 27 \\
\hline & $\mathrm{Si}$ & 51.45 & 54.57 & 6 \\
\hline \multirow[t]{6}{*}{$53 \%$ salt } & Al & 6.28 & 8.10 & 29 \\
\hline & $\mathrm{Ca}$ & 1.22 & 1.08 & 11 \\
\hline & $\mathrm{Fe}$ & 1.34 & 1.60 & 19 \\
\hline & $\mathbf{K}$ & 11.41 & 6.09 & 47 \\
\hline & $\mathrm{Na}$ & 31.48 & 21.79 & 31 \\
\hline & Si & 44.15 & 51.83 & 17 \\
\hline
\end{tabular}

a. Expected concentration $=$ concentration in salt $\mathrm{x}$ mass of salt + concentration in soil $\mathrm{x}$ mass of soil d. 
Table 16. Expected vs. measured $\mathrm{Na}, \mathrm{K}$, and $\mathrm{Cr}$ content of glass by nondestructive INAA analysis.

\begin{tabular}{lcccc}
\hline Type of glass & Element & $\begin{array}{c}\text { Expected } \\
\text { concentration } \\
(\mathrm{ppm})^{\mathrm{a}}\end{array}$ & $\begin{array}{c}\text { Measured } \\
\text { concentration }_{(\mathrm{ppm})^{\mathrm{b}}}\end{array}$ & $\begin{array}{c}\text { RPD-mass } \\
\text { difference }^{(\text {percent) }}\end{array}$ \\
\hline 25\% salt & $\mathrm{Na}$ & $74,300 \pm 0.5 \%$ & $64,600 \pm 0.5 \%$ & 13 \\
High & $\mathrm{K}$ & $42,800 \pm 26.5 \%$ & $36,950 \pm 17.8 \%$ & 14 \\
Alkaline & $\mathrm{Cr}$ & $170 \pm 33 \%^{\mathrm{e}}$ & $145 \pm 33 \% \mathrm{e}$ & 15 \\
$35 \%$ salt & $\mathrm{Na}$ & $106,750 \pm 0.5 \%$ & $90,600 \pm 0.5 \%$ & 15 \\
High & $\mathrm{K}$ & $54,110 \pm 29.2 \%$ & $51,000 \pm 16.9 \%$ & 6 \\
Sodium & $\mathrm{Cr}$ & $240 \pm 33 \% \mathrm{e}$ & $200 \pm 33 \% \mathrm{e}$ & 17 \\
$35 \%$ salt & $\mathrm{Na}$ & $106,740 \pm 0.5 \%$ & $92,000 \pm 0.5 \%$ & 14 \\
High & $\mathrm{K}$ & $54,100 \pm 30 \%$ & $42,800 \pm 19 \%$ & 21 \\
Sodium & $\mathrm{Cr}$ & $240 \pm 33 \% \mathrm{e}$ & $190 \pm 33 \% \mathrm{e}$ & 21 \\
\hline
\end{tabular}

a. Calculated based on concentration in salt $x$ mass of salt in batch + concentration in soil $x$ mass soil divided by final mass of melt. Expected content in glass (from INAA analysis of salts and soils), assuming no evaporation during vitrification.

b. Measured metal contents in glasses using INAA.

c. $\mathrm{RPD}=$ difference between expected and measured content in glass $=1$-measured content in glass/expected content in glass.

d. Averages of two sections of a single glass sample.

e. $\mathrm{Cr}$ results may be high because of interfering sodium. 
Table 17. Laboratory reproducibility of duplicate melts with Pad A salt and Acid Pit soil.

\begin{tabular}{|c|c|c|c|c|}
\hline Type of glass & Parameter & \multicolumn{2}{|c|}{$\begin{array}{l}\text { Replicate melts of } \\
\text { similar composition }\end{array}$} & $\begin{array}{l}\text { Difference } \\
\text { percent }\end{array}$ \\
\hline \multirow{4}{*}{$\begin{array}{l}\text { High alkaline } \\
\text { glass } 25 \% \text { salt }\end{array}$} & Density & 2.34 & 2.34 & $0^{\mathbf{a}}$ \\
\hline & $\begin{array}{l}\text { Percent } \\
\text { poured }\end{array}$ & 80 & 73 & 7 \\
\hline & $\begin{array}{l}\text { \% mass } \\
\text { reduction }\end{array}$ & 2 & 8 & 6 \\
\hline & $\begin{array}{l}\text { \% volume } \\
\text { reduction }\end{array}$ & 54 & 56 & 2 \\
\hline \multirow{4}{*}{$\begin{array}{l}\text { Medium alkali } \\
\text { glass } 28 \% \text { salt }\end{array}$} & Density & 2.17 & 2.22 & $4^{b}$ \\
\hline & $\begin{array}{l}\text { Percent } \\
\text { poured }\end{array}$ & 62 & 53 & 8 \\
\hline & $\begin{array}{l}\text { \% Mass } \\
\text { reduction }\end{array}$ & 25 & 22 & 9 \\
\hline & $\begin{array}{l}\% \text { Volume } \\
\text { reduction }\end{array}$ & 58 & 61 & 3 \\
\hline \multirow{4}{*}{$\begin{array}{l}\text { High alkali } \\
\text { glass } \\
35 \% \text { salt }\end{array}$} & Density & 2.44 & 2.31 & $5^{a}$ \\
\hline & $\begin{array}{l}\text { Percent } \\
\text { poured }\end{array}$ & 67 & 69 & 2 \\
\hline & $\begin{array}{l}\% \text { mass } \\
\text { reduction }\end{array}$ & 25 & 22 & 3 \\
\hline & $\begin{array}{l}\% \text { volume } \\
\text { reduction }\end{array}$ & 67 & 66 & 2 \\
\hline \multirow{4}{*}{$\begin{array}{l}\text { Very high } \\
\text { alkali } \\
46 \% \text { salt }\end{array}$} & Density & 2.45 & 2.17 & $12^{\mathrm{a}}$ \\
\hline & $\begin{array}{l}\text { Percent } \\
\text { poured }\end{array}$ & 92 & 85 & 7 \\
\hline & $\begin{array}{l}\% \text { Mass } \\
\text { reduction }\end{array}$ & 36 & 36 & 0 \\
\hline & $\begin{array}{l}\% \text { Volume } \\
\text { reduction }\end{array}$ & 73 & 70 & 3 \\
\hline
\end{tabular}

a. $R P D=$ difference of two values divided by their average.

b. Percent standard deviation of three values. 
generally yellow flaky material with some white chunks. Generally, the largest overall uncertainty is in the sampling and sample inhomogeneity rather than in the specific analytical technique.

Elemental analysis was performed on two Pad A salt samples and two Acid Pit soil samples using a variety of techniques is shown in Table 8. For example, the potassium content in Pad A salt was measured by ICP, INAA, AAS, and gamma counting at three different laboratories. Results agreed within the limits of the sample inhomogeneity, which was about $25 \%$. NIST standards were used in the ICP analysis of PCT leachates and glass wasteforms with an average 6\% RPD. Most measurements on the salt and soil wastes were performed twice on different samples to ensure validity of data, analytical method, and homogeneity of samples. Averages of measured values agree with one another within the homogeneity of the sample (reflected in the standard deviation percent on each value).

Accuracy and uncertainty of measurement data are addressed in laboratory procedures in Reference 5, Appendix. Specified error values or degrees of confidence in sampling and analysis or analysis, wherever applicable. Data and analytical methods were verified by duplication of measurements in many cases, with very good results. For example, the $\mathrm{K}$ contents in the Pad A salt sample were measured by INAA AAS and gamma counting. Most measurements on the salt and soil wastes were also performed twice on different samples to ensure validity of data, the analytical method, and homogeneity of samples.

Sodium and potassium concentration in the salts and soils were determined by INAA and AAS at the same lab, NRT. The results showed good agreement with those using other measurements of ICP and Gamma Spectrometry, Table 12; Na content as determined by AAS was 5\% lower $(189,100 \mu \mathrm{g} / \mathrm{g})$ and $\mathrm{K}$ was $8 \%$ higher $(81,600 \mu \mathrm{g} / \mathrm{g})$ than INAA. The results from elemental analyses of two wasteforms with similar initial batch formulas showed that the glass data has lower variation than the leachate data. The results show good agreement with some disparity in the $\mathrm{As}, \mathrm{Ba}$, and $\mathrm{Cd}$ contents in the glasses. These data seem to indicate that the reproducibility from an initial batch formula to the glass form is fairly good. However, reproducibility of the leaching procedures can yield more variation; a possible cause is that the total active surface areas of ground glasses for leaching varies widely from one sample to another.

The $\mathrm{Na}, \mathrm{K}$, and $\mathrm{Cr}$ contents in salt and soil samples, as determined by INAA, were used to predict the expected concentrations in the final glass. Table 12 lists these expected concentrations with those actually measured in the glass by INAA. Their content in the glass are from 6 to $21 \%$ lower than expected. This could be explained by some evaporation during the vitrification process or the density difference between the glass; the salts and soils has attenuated the glass results slightly. Metals volatilization was observed and quantified through a mass balance, but was less than $7 \%$. The absence of chloride, sulfate, and carbonate data prohibits an exact accounting for all species in the waste and glass. This type of offgas measurements will be of particular interest in the pilot-scale test. The consistency of the RPD's $15.1 \pm 4.5$ makes the contribution of a systematic measurement error more of a contributor to this difference. The volatility of sodium is much greater than chromium but does not appear significantly lower percentagewise in the glass. The density difference of the glass (2.3) from the soil (1.6) and salt (0.7) may contribute to the difference in the nondestructive INAA analysis for each species. 
There are also other factors that may contribute to differences between expected and measured concentrations in the glass among the different metals. The salt and soil samples were sieved, well mixed, and split before analyses and vitrification. The analyses for ICP from samples (other soil cores) showed more sample variability. Most of the differences in sample analysis are from this sample inhomogeneity rather than the technique used. Duplicate elemental analysis for similar glasses show close agreement more so than input ingredients despite possible nonhomogeneity of waste. Another factor is the margin of error associated with analytical measurement on the salt and soil samples.

Radionuclide results are fairly consistent considering the differences in sample size and sampling and analytical techniques. Apparent losses of spiked U-234 and Am-241 probably result from analytical error in gamma counting because of the higher density of the glass than either soil or salt. The Am-241 is detected by a lower energy gamma than the uranium and is more affected by the density difference between the standard and sample. Results are shown in Table 18. 
Table 18. Comparison of Pad A salt radionuclide results by destructive alpha spectrometry nondestructive gamma spectrometry.

\begin{tabular}{|c|c|c|c|c|}
\hline \multirow{2}{*}{$\frac{\text { Radionuclide }}{\mathrm{U}-238^{\mathrm{a}}}$} & \multicolumn{3}{|c|}{$\begin{array}{l}\text { Replicate Pad A salt composite samples } \\
\text { activity in } \mathrm{pCi} / \mathrm{g}\end{array}$} & \multirow{2}{*}{$\begin{array}{c}\begin{array}{c}\text { Standard } \\
\text { deviation } \\
\text { percent }\end{array} \\
0.9\end{array}$} \\
\hline & $63 \pm 4$ & $63 \pm 4$ & $64 \pm 4$ & \\
\hline $\mathrm{U}-238^{\mathrm{b}}$ & $58 \pm 1$ & $70 \pm 1^{c}$ & $58 \pm 7^{d}$ & 11 \\
\hline $\mathrm{U}-234^{\mathrm{a}}$ & $49 \pm 3$ & $50 \pm 3$ & $50 \pm 3$ & 1 \\
\hline $\mathrm{U}-235^{\mathrm{b}}$ & $2.1 \pm 0.02$ & $2.0 \pm 0.02^{c}$ & $1.0 \pm 0.04$ & 36 \\
\hline Pu-239a & $0.22 \pm 0.06$ & $0.27 \pm 0.07$ & $0.32 \pm 0.07$ & 19 \\
\hline Pu-238 ${ }^{d}$ & $0.29 \pm 0.06$ & $0.48 \pm 0.07$ & $0.47 \pm 0.07$ & 26 \\
\hline $\mathrm{Am}-241^{\mathrm{b}}$ & $0.26 \pm 0.1$ & $0.30 \pm 0.13$ & $0.30 \pm 0.02^{\mathrm{e}}$ & 8 \\
\hline$T^{b}$ & $1.2 \pm 0.06$ & $0.72 \pm 0.02^{c}$ & $0.70 \pm 0.04^{d}$ & 32 \\
\hline $\mathrm{Cs}-137^{\mathrm{b}}$ & $<0.1$ & $0.08 \pm 0.04^{\mathcal{c}}$ & $<0.1$ & \\
\hline $\mathrm{K}-40^{\mathrm{b}}$ & $75 \pm 2$ & $74 \pm 2^{c}$ & $86 \pm 3^{d}$ & 9 \\
\hline
\end{tabular}

Pad A salt data based on analyses of composited samples from one drum

a. Alpha spectrometry at INEL; destructive; uncertainty is analytical.

b. Gamma spectrometry at INEL on small $60 \mathrm{~g}$ sample; nondestructive; uncertainty is analytical.

c. Gamma spectrometry at INEL on large $358 \mathrm{~g}$ sample; nondestructive, uncertainty is analytical.

d. Gamma spectrometry at NRT on small $10 \mathrm{~g}$ sample; nondestructive, uncertainty is analytical. 


\section{CONCLUSIONS AND RECOMMENDATIONS}

\subsection{Conclusions}

The laboratory-scale melting of INEL's Pad A nitrate salts and Acid Pit contaminated soil generated over 30 sample wasteforms. Actual salt from a retrieved Pad A drum and characterized soils from the Acid Pit were mixed, melted, and leach tested. Nitrate and organics were destroyed, and volume and mass were reduced. Subsequent leach testing demonstrated complete nitrate destruction, low alkali metal, and no toxic metal or radionuclide leaching from the wasteform.

The laboratory-scale testing provided data applicable to treatment of other buried wastes, residuals, salts, sludges, and soils containing nitrates such as those from Pit 9, Acid Pit, Pad A at the RWMC and other DOE sites. It also demonstrated treatment of INEL salts and soils containing hazardous levels of toxic metals and low levels of TRU radionuclides. Glass samples were produced for destructive examination, characterization, leach testing, and archived. General objectives were achieved. These tests:

- Verified retention of metals and glass material during vitrification and in subsequent leaching. Wasteforms made in the test were leach tested for toxic metal, structural metal and radionuclide release. Four wasteforms with both high and low alkali, spiked with about $1 \%$ lead passed TCLP. Samples spiked with TRU showed no TRU nuclide leaching. Six wasteforms were tested for long-term leach characteristics and one was suitable as a high-level waste glass. The most durable glasses contained 20 to $25 \%$ salts; however, those very high in potassium and sodium content, 35 to $50 \%$ might still be acceptable.

- Demonstrated processing a variety of melt compositions with significant waste minimization. Sixty to seventy percent waste volume reduction and 10 to $30 \%$ mass reduction were typical. Melt densities of 2.2 to $2.4 \mathrm{~g} / \mathrm{cc}$ were produced, compared to 0.77 and $1.57 \mathrm{~g} / \mathrm{cc}$ for the original salt and soil.

- Demonstrated melt formulations likely to minimize production of nitrous oxide gases, refractory and electrode corrosion, and sample foaming during production by addition of carbon and boron.

- Demonstrated nitrate destruction. No nitrate was detected in TCLP leachate from the glass melt.

- Provided salt/soil/additive compositions and ratios that produce glass products and viscosity low enough for commercial melter operation at $1550^{\circ} \mathrm{C}$. Temperatures below generally require high alkali contents to process INEL soils above on pilot-scale melter operation.

- Produced 20 wasteforms by melting mixtures of 15 to $50 \%$ Pad A salt and 40 to $80 \%$ Acid Pit soil in crucibles. Several of these glass wasteforms were produced at higher alkali and lower silica contents than originally thought possible. 
- Selected several additives compatible with full-scale operation; in particular, carbon and boric acid seemed to minimize crucible corrosion and, thus, possibly electrode, refractory, and other equipment corrosion.

- Produced uniform glass melts where all metals and soil particles were completely incorporated.

- Documented on video laboratory-scale melting.

The nitrate salt/soil testing demonstrated the feasibility of ex-situ vitrification technology to fix radionuclides and metals in a glass/basalt matrix, remove nitrates and organics, components which make up Pad A salts and soils such as those in the Acid Pit. The technology demonstration has application to the treatment of most radioactively contaminated nitrate salts within the DOE system. The project demonstrated coprocessing of two different hazardous radioactive waste streams. Ex-situ vitrification performed well with a variety of mixtures and considerable waste minimization. Success was measured by the ability of the technology to (a) destroy nitrates in a variety of wastes, (b) form a leach resistant solid, and (c) minimize final waste volume.

\subsection{Recommendations}

This laboratory-scale test simulated ex situ vitrification treatment of actual radionuclide contaminated INEL Pad A nitrate salts and soils from the Acid Pit. Salt/soil coprocessing was studied in three areas: waste processibility, wasteform durability, and waste minimization. Processibility was judged to be adequate as measured by qualitative viscosity measurement, crucible and electrode corrosion, and offgas and reactivity observations. Durability was excellent as determined by EPA TCLP and NRC PCT leach testing of high alkali, low alkali, toxic metal, and radionuclides spiked wasteforms. Waste minimization was excellent as measured by the mass and volume reductions of the waste and final density increase.

The leachates contained no nitrates, passed TCLP, and had low matrix disintegration if the alkali content was under $25 \%$. Waste minimization of up to $77 \%$ by volume and $41 \%$ by mass with wasteform densities of $2.4 \mathrm{~g} / \mathrm{cc}$ were produced (compared to 0.77 and $1.57 \mathrm{~g} / \mathrm{cc}$ for the original salt and soil). Destructive examination revealed some mass loss, primarily sodium and potassium. Offgas was not analyzed so the conversion of nitrous oxide to nitrogen is unknown. Melt formulations using carbon and boron and calcium minimized sample foaming and corrosion, yet produced glass with viscosity low enough for commercial melter operation. Future pilot-scale testing should start with a salt-to-soil ratio of 0.43 , an alkali content of no more than $25 \%$, sufficient carbon (4 to $7 \%$ ) and 2 to $3 \%$ boron to chemically reduce the available nitrate.

Lab-scale testing on low-level contaminated salts and soils has been successful enough to merit pilot-scale testing. Pilot-scale testing will extend the benefits beyond Pad A and Acid Pit/ISV projects, to all of the buried waste programs and other DOE facilities. Pilot-scale vitrification will yield different offgas compositions than laboratory-scale testing, including gases from nitrate and sulfate decomposition. Although it is likely that carbon addition achieved some reduction in $\mathrm{NO}_{\mathrm{x}}$ production in the laboratory-scale testing, only during pilot testing in a joule melter with a cold-cap can the melt be expected to capture significant quantities of $\mathrm{NO}_{\mathrm{x}}$ and minimize evaporation of volatile glass components. 
Decomposed nitrates will produce $\mathrm{NO}_{\mathrm{x}}$ unless converted to nitrogen by a reductant and operating conditions. Sulfates and halides have limited solubility in the glass melt and may concentrate in the cold-cap unless flushed occasionally through the addition of wastes containing low levels of these components. Retention of volatile metals is also expected to be enhanced in the pilot-scale testing. These corrosive and undesirable offgas constituents were not measured or actively controlled in the lab-scale testing. Pilot-scale testing will address minimization of volatile $\mathrm{NO}_{x}$ sulfate, and halide acid gas production and volatilization of metals. It is recommended that pilot-scale testing start with initial waste composition of salt-to-soil ratio of $0.43,25 \%$ alkali nitrate salts, $5 \%$ boron, and $4 \%$ carbon.

Coprocessing of soils and salts is an effective remediation method for destroying nitrate salts while stabilizing the radiologically contaminated salts. The test provided the range of salt/soil/additive compositions that can be efficiently processed by a high-temperature melter that will fix radiological contaminants, destroy nitrates, and minimize overall volume and mass. These data will be applicable to other buried wastes, residuals, and soils at the RWMC and other DOE sites containing nitrate salts, sludges, and contaminated soils. 


\section{REFERENCES}

1. A. J. Johnson and P. M. Arnold, Waste Generation Reduction Nitrates Comprehensive Report of Dinitrification Technologies, Rockwell International, RFP 3899, March 1986, p. 3.

2. V. E. Halford et al., "Remedial Investigation/Feasibility Study for Pad A Operable Unit 7-12," WAG-7 RWMC INEL, Volume 1, EGG-WM-9967, EG\&G Idaho, Inc., July 1993.

3. D. K. Jorgensen et al., WAG-7 Acid Pit Summary Report, EG\&G Idaho, Inc., EGG-ERD-10242, July 1992.

4. P. Shaw, Final Technology and Vendor Evaluation Report Pad A Treatability Study Project, EG\&G Idaho, Inc., EGG-WTD-91030, October 1991.

5. Pad A Treatability Study, Laboratory Scale Vitrification of Low Level Radioactive Wastes: Nitrate Salts and Soils, Final Test Report, NRT Corporation, NRT-Project 3951, EG\&G Contract 91-133248, November 9, 1992. 